\title{
SOME LEGAL ASPECTS OF IIFE INSURANCE TRUSTS
}

\author{
JoHN HaNNA

\section{INTRODUCTION}

A life insurance trust is a trust whose res consists, in whole or in part, of a life insurance policy. ${ }^{1}$ While an historian might find early counterparts of the insurance trust, ${ }^{2}$ it is for all practical purposes as contemporaneous as the radio, and its possibilities are as uncertain. In fact, the development of the insurance trust dates from 1920 , and the $\$ 700,000,000$ in insurance policies placed in trust in 1928 makes it almost possible to designate that year as marking their real beginning, although policies amounting to $\$ 541,000,000$ were assigned to trustees in the five years from 1923 to $1928 .^{3}$

Two principal types of life insurance trusts are recognized, depending upon the method of paying the insurance premituns. In an unfunded trust, while the trustee holds the policies, the

${ }^{1}$ The author is indebted, for help in the preparation of this article, to his assistant, Mr. Samuel Silverman, Decisions Editor of the Columbia Law Review, and to Messrs. Charles Looker, Robert L. Redfield, Jr., David M. Solinger, and Miss Helen H. Robinson, members of the 1929 seminar in decedents' estates at the Columbia University Law School.

2 Bassil v. Lister, 9 Hare 177 (Eng. I85I) is a case in which the English Chancery Court sustained the legality of an arrangement by which Lister insured the lives of his two sons and by will provided for the continuance of premium payments out of the income of his estate. This English trust differed from modern life insurance trusts in that the policies were not on the life of the creator or settlor, and the trust was created by will, thus taking effect only at the death of the settlor.

The Girard Trust Company of Philadelphia established, on June 13, 1859, what appears to have been the first life insurance trust in this country. The Providence Life and Trust Company of Philadelphia, on January 27, 1877, wrote a life insurance trust under which the settlor assigned all his interest in a policy upon his life to the company, which as trustee was to collect the insurance money from itself as an insurance company, paying the income to the settlor's widow for life and the principal, at her death, outright to his daughter. The Northern Trust Company of Chicago was the first trust company, which was not also an insurance company, to receive a life insurance trust. This was on March I8, I897. See Stephenson, Living Trusts (1926) I9; (I926) 42 TRUST COMPANIES 867.

${ }^{3}$ See the address by F. H. Sisson, I928-A Record Year for Trust Service, published by the Guaranty Trust Company, New York. Mr. Sisson reports the results of a survey made by the Trust Company Division of the American Bankers Association. 
creator or settlor pays the premiums directly to the insurance company. The trustee has no active duties until the death of the insured. Upon the happening of that event, he collects the proceeds of the policies, and invests or otherwise disposes of them as the settlor has directed in the trust agreement. The unfunded trust is the more popular form, ${ }^{4}$ since it requires the least initial capital; and most active business men think they can invest their own accumulated funds more profitably than can a trust company. In a funded trust, the settlor, at the time of the agreement, deposits with the trust company sufficient money or securities so that the trustee will be able to pay the premiums on the policies out of the income of the fund. The trust res, on the death of the settlor, consists not only of the proceeds of the insurance policies, as in the unfunded trust, but also of the fund from which the money for premiums has been derived.

Minor variations from the two main types are found in the cumulative and retiring insurance trusts. In the cumulative type the settlor pays periodically to the trustee a fixed sum which is more than enough to cover the premiums on the policies. The trustee pays the premiums and invests the surplus. This invested surplus eventually becomes large enough to provide an income sufficient to pay the premiums, and an ordinary funded trust has been created. In the retiring insurance trust, as the surplus fund grows, insurance is retired, resulting eventually in an ordinary trust of personal property without insurance features.

A classification of insurance trusts from the standpoint of function, instead of method of creation, would require mention of the business life insurance trust. Its purpose is to provide a fund 'for the purchase of a deceased partner's interest by the surviving partners, or the purchase of a deceased shareholder's interest in a close corporation by the surviving shareholders. The life of each person concerned is insured to the extent of the value of his interest, and the policies are made payable to the trustee under the trust agreement. While it would be possible to have the policies payable directly to the survivors, it is usually advantageous to have

- Leading trust companies estimate that about 95 per cent of insurance trusts are unfunded. 
a trustee in order to assure all parties that the business plans contemplated when the policies were executed will be carried out. ${ }^{5}$

The forms of business life insurance trusts are much less standardized than the forms for the ordinary funded and unfunded trusts. If a partnership, with two partners having an equal interest in the business, wishes to set up a business insurance trust, each partner insures the life of the other, making the policy payable to the trustee, and obligates himself to maintain the insurance so long as the agreement remains in force. The agreement provides that the survivor shall have the right and the duty to purchase the other's share. If a close corporation is involved, it is sometimes provided that the corporation shall take out the insurance, pay the premiums, and buy the shares of the deceased shareholder. The power of a corporation to assume such obligations is doubtful in many jurisdictions, and some trust companies, on that account, will not accept such trusts. In New York, for example, Section 664 of the Penal Law ${ }^{6}$ provides in part as follows:

"A director of a stock corporation, who concurs in any vote or act of the directors of such corporation, or any of them, by which it is intended:

"5. To apply any portion of the funds of such corporation, except surplus, directly or indirectly, to the purchase of shares of its own stock . . . Is guilty of a misdemeanor."

In Topken, Loring \& Schwartz, Inc. v. Schwartz ${ }^{7}$ an employee of a corporation had agreed to sell, and the corporation had agreed to buy, certain shares of stock in the corporation owned by the employee. The employee refused to sell. Although there was no evidence that the corporation had no surplus, the New York Court of Appeals denied specific performance to the corporation, despite the fact that the shares were unobtainable in the market. The court decided that, since the corporation might not have had a surplus at the time of performance, its promise to buy

${ }^{5}$ The Financial Digest, May, I928, 4. 5732

' $N$. Y. Penal Law (I917) §664, N. Y. ANn. Cons. Laws (2d ed. IgI7)

${ }^{7} 249$ N. Y. 206, 163 N. E. 735 (1928). 
might not be enforceable; hence there was no consideration for the promise to sell.

A further difficulty might arise if the corporation were the beneficiary of the insurance policy, and the insured shareholder died in straitened circumstances. Statutes generally provide that beneficiaries of insurance policies are entitled to the proceeds as against the creditors of the insured, with some limitations, ${ }^{8}$ but it is by no means settled that such statutes apply when a corporation is the beneficiary. These difficulties may be avoided by having each shareholder take out policies on the lives of the others for an amount sufficient to buy his proportionate part of the shares of a deceased shareholder.

Since one of the main objects of the business trust is to assure a fair price for the shares in a partnership or corporation, the clauses in the trust agreement, fixing the price, are among the most significant. The parties may, and sometimes do, agree that this price shall be determined by the amount of insurance. More often an arrangement is adopted by which the value of the business, including its good will, shall be revalued periodically. A further desirable provision is to change the amount of the insurance to correspond to the changed valuation. If the business insurance trust involves a close corporation, the shareholders, on making the agreement and taking out the policies, will generally assign their shares to the trustee, to facilitate carrying out the pro- . visions of the trust on the death of a shareholder.

\section{CREDITOR'S Rights}

One of the chief advantages claimed for insurance trusts is that they enable the settlor to build up a fund for his dependants, which will be free from the claims of his creditors. It will be wise at the outset to distinguish between the rights of creditors of the cestui que vie (the person on whose life the insurance is carried) and the creditors of the settlor or insured, where the settlor or insured is not the cestui que vie. A cestui que vie who is

${ }^{8}$ New York InSURANCE LAw (1928) $\S 55-a, N$. Y. Cons. LAws ANN. (Supp. I928) 507 . 
neither the insured nor a beneficiary has no interest in the policy, and his creditors have no claim to it. $^{9}$

No cases seem to have presented squarely the problem of the rights of creditors of the settlor in a funded insurance trust. So far as the insurance itself is concerned, if the insurance is payable to the estate of the insured, the proceeds must be distributed by his executor among the creditors of the estate. ${ }^{10}$ Where the policy is payable to some third person, it would seem to follow that, if the insured has only a privilege of paying the premiums, and all rights are vested in the beneficiary, the insured's creditors or their legal representatives are entitled to nothing. It is now well settled, in every state except Wisconsin, ${ }^{11}$ that, if the right to change the beneficiary has not been reserved, the interest of the beneficiary is vested in the sense that it cannot be defeated if the conditions precedent to the duty to pay are satisfied. ${ }^{12}$ It is no longer the property of the insured, and his creditors can claim no share of the proceeds, ${ }^{13}$ unless there has been a fraudulent conveyance. ${ }^{14}$

These rights of the beneficiary were at first secured through statutes intended to protect the wife and children of the insured. The two earliest enactments provided that a married woman could take out insurance on the life of her husband and receive the proceeds free from claims of his creditors or their representatives. ${ }^{15}$ Later statutes in most of the states are to the same effect. In North Carolina a similar provision is thought impor-

${ }^{9}$ In re Hartman's Estate, 126 Misc. 862, 215 N. Y. Supp. 802 (1926), aff'd 220 App. Div. 755, 222 N. Y. Supp. 817 (1927).

${ }^{10}$ Vance, Insurance (Ig04) 405.

${ }^{11}$ In re Breitung's Estate, 78 Wis. 33, 46 N. W. 891,47 N. W. I7 (1890); Wis. Stat. (1927) \& 206.

I2 Vance, The Beneficiary's Interest in a Life Instrance Policy (1922) $3 \mathrm{I}$ YALE L. J. 343.

${ }^{13}$ In accord with this view see Matter of Thompson, 184 N. Y. $36,43,76$ N. E. 870, 872 (1906), where the court said: "The amount of insurance purchased by the excess of premiums paid out of the husband's property did not belong to him in his life time and formed no part of his estate after his death. - He never owned any part of the policy which belonged wholly to his wife. . ."

${ }^{14}$ VANCE, InSURANCE (I904) 407.

${ }^{25}$ N. Y. Laws I840, c. 80 ; Mass. Laws 1844 , c. 82, \$§ 2, 3. See 2 JoYCE, INSURANCE (2d ed. I9I7) \& 879. 
tant enough to warrant its being made a part of the constitution. ${ }^{16}$ In Pennsylvania the statute insures the proceeds to the wife, children, or other relative dependent on the insured, ${ }^{17}$ while the Massachusetts statute applies to the proceeds of any policy, ${ }^{15}$ as does the recent New York statute. ${ }^{19}$ Attention should be called to the appropriate provisions of the California Code. It is provided that all moneys and benefits accruing from insurance shall inure to the named beneficiary, if the annual premiums do not exceed $\$ 500$, and, if they do, "a like exemption shall exist which shall bear the same proportion to the moneys, benefits, privileges, and immunities so accruing or growing out of such insurance that said five hundred dollars bears to the whole annual premiums paid." 20

The New York statute ${ }^{21}$ is similar to that of California, except that all the excess is made "primarily liable for the husband's debts". This excess, however, cannot be reached directly, but only by a bill in equity, and after the other assets of the estate have been found insufficient. ${ }^{22}$ A creditor need not wait for the death of the insured and perhaps run up against the bar of the Statute of Limitations, but may, during the life of the insured, impose a lien on proceeds procured with premiums in excess of $\$ 500$, and may enjoin the insured and his wife from assigning the policy except in subordination to the rights of creditors. ${ }^{23}$ Just what the effect is in New York of a reserved right to change the beneficiary is not clear. One case indicates that, if this right is reserved, the creditor will be entitled to no rights under the policy, ${ }^{24}$ while an earlier case seems to reach the opposite conclusion. ${ }^{2 \bar{J}}$

${ }^{10} \mathrm{~N}$. C. Constitution, art. $\mathrm{X}, \S 7$.

${ }^{17}$ PA. Stat. (West, 1920) § 12262.

${ }^{18}$ Mass. Gen. Laws (192I) c. I75, § 125.

${ }^{20}$ Subra note 8.

${ }^{2}$ Cal. Codes of Civ. Proc. (Deering, I923) $\S 690$ (18).

${ }^{3}$ N. Y. DoM. ReL. LaW (ig09) $\S 52 ;$ N. Y. Asix. Coxs. Laws ( $2 d$ ed. I917) 1887.

* Matter of Thompson, supra note 13 .

${ }^{2}$ Stokes v. Amerman, I2I N. Y. 337, 24 N. E. 819 (I890).

as Grems v. Traver, 87 Misc. 644 , I48 N. Y. Supp. 200 (1914), aff'd. I64 App. Div. 968, I49 N. Y. Supp. 1085 (I914).

${ }^{3}$ Cavagnaro v. Thompson, 78 Misc. 687, I38 N. Y. Supp. 8ig (I9I2). 
The New York law has recently been changed by Section $55^{-a}$ of the Insurance $\mathrm{Law},{ }^{26}$ which provides:

"If a policy of insurance . . . is effected by any person on his own life or on another life, in favor of a person other than himself, . . . the lawful beneficiary or assignee thereof, other than the insured or the person so effecting such insurance, . . . shall be entitled to its proceeds and avails against creditors and representative of the insured and of the person effecting same, whether or not the right to change the beneficiary is reserved and permitted . . . Provided . . that . . premiums . . paid with intent to defraud creditors . . . shall enure to their benefit."

This statute has been held applicable in bankruptcy proceedings. ${ }^{2 \bar{t}}$ The court said:

"while the insured may still change the beneficiary, and appoint to himself under the reserved power, by reason of the New York Insurance Law, he cannot be compelled to do this, as he would have been prior to the enactment of $55^{-a}$ because to do so would deprive the beneficiaries of their interest." 28

The New York Court of Appeals has held recently. in Chatham Phenix National Bank v. Crosney, ${ }^{29}$ that the provision of Section 52 of the Domestic Relations Law making insurance moneys acquired by the payment of premiums in excess of $\$ 500$, and in fraud of creditors, liable for the husband's debts, was impliedly repealed by the new Section $55^{-a}$ of the Insurance Law. This decision reversed the holding of the Appellate Division to the effect that when a husband insures his life in favor of his wife he acts as her agent, and therefore it is not a case of insurance "effected by any person . . . in favor of a person other than himself". 30

* Supra note 8.

${ }^{2}$ In re Messinger, 29 F. (2d) 158 (C. C. A. $2 \mathrm{~d}, 1928$ ).

${ }^{\infty}$ Ibid. at 160 .

${ }_{25}^{25}$ N. Y. 189 (1929).

${ }^{30} 224$ App. Div. 58, 229 N. Y. Supp. 140 (I928). The court cited Wagner v. Thieriot, 203 App. Div. 757,197 N. Y. Supp. 560 (1922), aff'd, 236 N. Y. 588 , 142 N. E. 295 (1923). 
During the life of the insured the question usually arises under the Federal Bankruptcy Act. Section 6 allows the bankrupt the "exemptions which are prescribed by the State laws in force at the time of the filing of the petition". 31 Section 70 in effect provides that all property shall pass to the trustee in bankruptcy which the bankrupt could, by any means, have transferred, provided that, if the bankrupt has a life insurance policy with a cash surrender value, payable to himself, he may pay to the trustee such cash surrender value and then hold "such policy free from the claims of creditors participating in the distribution of his estate". ${ }^{2}$ The relation of these sections was decided by the case of Holden $v$. Stratton, ${ }^{\mathbf{3}}$ where the court held that Section 70 was limited by Section 6, rather than that Section 6 was limited by Section 70 ; that is, that insurance exempt by the state statute did not pass to the trustee in bankruptcy, even though it could have been transferred by the bankrupt. The construction of the proviso in Section 70-a came before the court in the case of Burlingham v. Crouse, ${ }^{34}$ where the question presented was whether the statute meant that all insurance passes to the trustee in bankruptcy but the bankrupt can regain those with a cash surrender value, upon payment of such surrender value, or that only those policies pass which have a cash surrender value. The court, by its decision, adopted the latter construction, saying,

"We think it was the purpose of Congress to pass to the trustee that sum which was available to the bankrupt at the time of the bankruptcy as a cash asset, otherwise to leave to the insured the benefit of his life insurance." 35

But the Supreme Court has not been too lenient on the bankrupt, for it has held that, though there is no express provision for a cash surrender value, yet, if it is the custom of the company to pay one, the policy has a cash surrender value under the act. ${ }^{36}$

\footnotetext{
s1 30 Stat. 548 (1899), II U. S. C. § 24 (1926).

${ }^{32} 30$ Stat. 565 (1899), II U. S. C. § I10 (1926).

${ }^{23}$ Ig8 U. S. 202, 25 Sup. Ct. 656 (I905).

${ }^{31} 228$ U. S. 459, 33 Sup. Ct. 564 (1913).

${ }^{35}$ Ibid. 473,33 Sup. Ct. at 568 .

${ }^{30}$ Hiscock v. Mertens, 205 U. S. 202, 27 Sup. Ct. 488 (1907).
} 
There was formerly a great deal of confusion in the lower federal courts as to the effect of a reserved right to change the beneficiary; $;^{37}$ but the Supreme Court finally settled this question, in the case of Cohen $v$. Samuels, ${ }^{38}$ by allowing the trustee to have the cash surrender value of policies payable to a person other than the insured, but in which the insured had reserved a right to change the beneficiary.

It is pertinent here to consider the policy of the law in regard to the claims of creditors to the insurance of their debtor, because, for the purposes of the principal problem, this is more important than the settled law. The statutes, in general, protect the beneficiary from claims of the insured's creditors. It is submitted that this should be the law, even in the absence of statutes, because it is the logical result of the proposition that the interest of the beneficiary is vested and indefeasible, and it is in line with the policy which gave rise to the statutory declarations. The attitude of the courts is clearly stated in Weil $v$. Marquis: ${ }^{39}$

"The policy of the law, even where the rights of creditors may be adversely affected, favors the wife to whom her husband has attempted to secure the benefit of insurance upon his life . . ."

A striking example of the application of this policy is contained in the leading case of Central Bank v. Hume. ${ }^{40}$ Hume had several life insurance policies payable to his wife. For about five years prior to this action he had paid premiums on them, although during that time he was insolvent. After his death a creditor sought to get the money paid for premiums while the deceased was insolvent. The court decided in favor of the wife, with the result that the creditors got nothing. The court said:

In re Orear, I78 Fed. 632 (C. C. A. 8th, 1910), holding that the cash surrender value of such a policy passed to the trustee in bankruptcy. Contra: In re Young, 208 Fed. 373 (N. D. Ohio I912).

${ }^{39} 245$ U. S. 50, 38 Sup. Ct. 36 (1917).

${ }_{256} \mathrm{~Pa} .608,6 \mathrm{I}$, Ior Atl. 70, 7I (I9I7).

${ }^{40}$ I28 U. S. I95, 9 Sup. Ct. 4I (I888). This situation is treated in Williston, Can an Insolvent Insure $H$ is Life for His Wife's Benefit? (I89I) 25 AM. L. REv. 185 . 
"Conceding, then, in the case in hand, that Hume paid the premiums out of his own money, when insolvent, yet, as Mrs. Hume and the children survived him, and the contracts covered their insurable interest, it is difficult to see upon what ground the creditors, or the administrators representing them, can take away from these dependent ones that which was expressly secured to them in the event of the death of their natural supporter." 41

Whether this attitude will continue is, of course, difficult to say. If insurance is used as a protection or in the nature of an indemnity contract, the courts will probably favor the beneficiary; but, on the other hand, if, in order to evade creditors or taxation, insurance is used merely as a device for enlarging the estate, one cannot be nearly so confident in predicting the judicial attitude.

Turning to the specific problem of the creditor's rights against an insurance trust, the simplest case is one where the trust fund is to become a part of the estate of the settlor, or is to be paid over to his executor and distributed according to the will of the settlor. During the life of the insured the trust would be for the benefit of the settlor; he would be the sole cestui que trust; and his creditors would be entitled to rights under the insurance contract and to the securities held in trust. The trustee can have no interest in the proceeds, so that the fact that he is the named beneficiary should make no difference. After the death of the insured, the whole trust, having become, by its terms, part of the assets of the creator, would, of course, be available to his creditors.

A more difficult problem is raised if the ultimate beneficiary of the trust is the wife of the settlor. Let us assume first that the trust is irrevocable, and that no right to change the beneficiary has been reserved in the contract of insurance. If there has been no intent to defraud creditors, it is difficult to see how this trust differs from any other trust created inter vivos. This would undoubtedly be so, unless the court should adopt the suggestion made by Surrogate O'Brien in In re Hartman's Estate, ${ }^{42}$ that an insurance trust is one for the benefit of the settlor because today

'2 Central Bank v. Hume, supra note 40, at 208, 9 Sup. Ct. at 45.

-Supra note 8. 
every man feels a need for insurance and so the trust is one which gives solace and comfort to the creator by providing for this need. Moreover, even without the trust, the beneficial interest of the wife in the insurance would be vested and so the husband would have no rights which his creditors could claim. It would seem clear that, on the death of the insured, in those states which provide that the proceeds of insurance shall be exempt from claims of creditors of the insured or the husband, such creditors could have no rights. In New York and California, however, the question is more complicated, because of the peculiar provisions of the statutes of those states.

The problem is squarely raised whether the courts will give to this new device the legal consequences of an insurance contract and allow the creditors their share, or regard it as a trust and refuse to allow the creditors anything. In New York the statute ${ }^{43}$ clearly provides that proceeds procured with premiums of more than $\$ 500$ shall be liable to creditors' claims, in the case of an unfunded trust. Whether this will be extended to cover a funded trust would seem to depend on the attitude of the court. If a court should regard the iunded trust with favor, or the statute with disfavor, it would not be compelled to extend the rule, because a distinction could be made on the ground that, in an unfunded trust, the trust res was only the insurance proceeds, which could be identified and claimed by a creditor. In a funded trust, however, the proceeds become an integral part of the trust created inter vivos, and, if the creditors could not attack the whole trust, they could not attack a part of it. It would be more logical to argue that the difference between a funded and unfunded trust is not so great as to make it necessary to refuse creditors rights in the one when they are given rights in the other, because the insurance proceeds come to the trustee in cash, and there is little difficulty in removing it, or the securities bought with it, without disturbing the trust as a whole. It is true that in the past the wife's interest as the beneficiary of an insurance policy has been protected by the courts; but, if it seems to the court, especially in the first few cases

${ }^{3}$ Supra note 21 . 
to arise, that the trust is being used to evade just claims, it may easily be that the trust device will be ignored.

Suppose that the trust is revocable. Clearly, under the Bankruptcy Act, the trust assets are available to creditors. ${ }^{44}$ But if the trust is by its terms irrevocable, and yet the contract of insurance has in it a reserved right to change the beneficiary, the same problem would arise as has been discussed previously, and the result of the case would depend on which of the two clauses the court thought should govern.

No funded insurance trust has yet been held invalid as an accumulation, ${ }^{4 \overline{5}}$ but, if one should be, other questions would arise. If the income goes to the settlor, then it would be a trust for the benefit of the settlor and so subject to his creditors. ${ }^{40}$ But if the income goes to the next eventual estate, ${ }^{4 \pi}$ the questions would, from the point of view of a creditor, be the same as if the trust were not invalid as an accumulation.

Thus it may be suggested that a funded insurance trust has no legal functions which are essentially different from insurance. In other words, the purpose of a funded insurance trust is to accomplish that which insurance alone accomplishes, unless there is a desire to avoid liabilities such as taxation or creditors' claims. In view of this, it is submitted that if insurance trusts are a useful device their successful execution should be aided and not hindered by the courts, but, on the other hand, where an attempt is made to set up the trust in order to avoid duties and liabilities which would otherwise attach to the insurance, the technical bar of a trust should not be permitted to be effectively interposed.

Creditors of the beneficiary of a funded insurance trust are faced with few problems that are peculiar to such trusts. In general, their rights will depend on the nature of the beneficiary's interest, which will, in turn, be determined by the terms of the trust. After the interest of the beneficiary vests in possession,

\footnotetext{
"Supra note 32.

see Bogert, Funded Insurance Trusts and the Rule against Accumulations (Ig24) 9 Corn. L. Q. II3. See also N. Y. Personal Property Law (1923) \& 16.

${ }^{40}$ GlenN, Creditors' Rights and Remedies (19i5) § 40.

${ }^{47}$ N. Y. Real Property Law (1923) $\$ 63$.
} 
the insurance proceeds become a part of the trust res and the whole should be treated as any other trust of personalty. From the point of view of the beneficiary this trust has no characteristics of insurance, and is not different from a situation where the insured makes the policy payable to his executor and directs the executor to hold the money in trust for the named beneficiary. ${ }^{48}$

\section{The Rule Against Perpetuities}

A pitfall carefully to be avoided in the creation of life insurance trusts is the rule against perpetuities. While an extended discussion of this highly technical subject is not within the scope of this article, ${ }^{49}$ a brief mention of the rule, pointing out the main problems involved in the application of the rule to insurance trusts, will not be out of place.

The rule against perpetuities, designed to aid the free circulation of property, requires that by the end of a certain period there shall be persons alive who, by joining, can convey absolute title to the property, and that by the end of that period the interest of each person in that property shall have become fixed and certain ( $i$. e., have vested) as vested life estates, vested remainders, etc. If, by any possibility, these conditions might not be satisfied within

4s In most states the settlor can provide in the trust instrument that the interest of the beneficiary in the life income from a trust shall be inalienable and free from the claims of the beneficiary's creditors. He cannot, in general, so limit a beneficiary's interest in the principal fund. Therefore, if a settlor provided that his son should receive the income from the proceeds of the policy until he was thirty, and that the son should then receive the principal fund, the settlor could provide that the only interest which the son could assign, or which would be liable for his debts, would be the right to receive the principal at the age of thirty. In New York and several other states the settlor cannot, in general, renoier an alienable trust inalienable; but the statute provides that the interest of a beneficiary to collect the income of real or personal property and apply it to the use of, or pay it over to, the beneficiary, is inalienable and exempt from his debts up to a sum reasonably necessary for his support and maintenance. This sum varies with the person and usually is liberal. $N$. Y. Real Property Law (1923) \$ I03; N. Y. Personal Property Law (I923) $\S I 5$.

The validity of restraints on alienation in the different states is discussed in Gray, Restraints on Aifienation (2d ed. I895). For the rule in each state, see LoRING, A TRUSTEE's HANDBOOK (4th ed. I928). See also Griswold, Reaching the Interest of the Beneficiary of a Spendthrift Trust (I929) 43 HaRv. L. REv. 63.

${ }^{49}$ For exteinded discussions, see Gray, Rule against Perpetuities (3d ed. I9I5); Kales, Future Interests (2d ed. 1920); Chapin, Suspension of THE Power of AIIENAtion ( $3 \mathrm{~d}$ ed. I928). Káles writes chiefly about Illinois law and Chapin about the law of New York. 
the permissible period, the whole gift is bad. At common law this period was twenty-one years after the death of the survivor of any number of persons who were alive at the time of the creation of the interests, with an allowance between the death and the beginning of the twenty-one years of an actual period of gestation of an infant conceived, but not born, before the death of such survivor. ${ }^{50}$ In some states this period has been changed by statute. $^{.11}$

Where an actual minority is a part of the permitted period, the minority need not be that of a person in being at the creation of the interests, but the minor must be born, or at least conceived, before the end of the lives in being at the creation of the interests.

In all cases, the measuring "lives in being" must be in being at the date of the creation of the interests involved. ${ }^{52}$ In the case of a will, this means at the testator's death, since that is the date as of which the will speaks, and not the date of the execution of the will. In the case of any other instrument, the lives must be in existence at the date of the instrument. Since very few insurance trusts are created by will, most of them fall into the latter category. The difference becomes important in attempting to provide for after-born children, who will, of course, be in being at the date of the testator's death, but who are not in being at the date of the trust agreement.

Although the duration of a trust is, in general, not limited by the rule against perpetuities, ${ }^{53}$ yet, if the interest of the beneficiaries of the trust is inalienable, in New York, and other jurisdictions having similar statutes, the trust must be limited so as to end of necessity within the permitted period from the date of the trust instrument, even though the interests of all the parties have finally vested. ${ }^{54}$ In New York ${ }^{55}$ the interest of the beneficiary of a trust in which the duty of the trustee is to receive the rents

\footnotetext{
${ }^{\infty}$ See Gray, op. cit. supra note 49, c. V and c. VI.

"See appendix for these changes.

s2 Gray, op. cit. supra note 49, § $20 \mathrm{I}$.

${ }^{2}$ Ibid. $\$$ 232-245(h).

s Coster v. Lorillard, 14 Wend. 265 (N. Y. 1835); $c f$. ORLA. Comp. Stat. AN.. (I92I) § 8412.

in. Y. Real Property Law (1923) § t03; N. Y. Personal Property LAW (1923) § I5.
} 
and income of real or personal property and apply them to the use of, or pay them over to, the beneficiary, is inalienable by statute. This is the usual type of trust.

Therefore, the case of greatest difficulty presents itself in New York, where, in addition to the statutory inalienability of the beneficiaries' interests, there are the statutes limiting the period of the rule to two lives in being at the date of the trust instrument. Therefore, a trust to divide the income from the insurance proceeds among $A, B$, and $C$, three named persons in being, and, on the death of the survivor of them, to pay the principal to $D$, another named person in being, would be invalid in New York, though valid in most other jurisdictions. The interest of each beneficiary is vested, but the trust is not to end until the expiration of three lives in being at the date of the trust instrument.

In jurisdictions which do not follow the New York statutes, the duration of trusts is not limited by the period of the rule, even though the interests of the beneficiaries are inalienable.

As has already been indicated, the desires of most settlors can be accomplished in any jurisdiction, without violating the rule, provided the rule is considered at the time the trust instrument is drawn.

It seems that the rule against perpetuities does not apply to the settlement options of insurance companies, although this has been doubted. ${ }^{56}$

\section{Insurance Trusts and the LaW of Accumulations}

The Century Dictionary defines an accumulation as,

"The adding of the interest or income of a fund to the principal, pursuant to the provisions of a will or deed preventing its being expended. The law imposes restrictions on the power of a testator or creator of a trust to prohibit thus the present beneficial enjoyment of a fund in order to increase it for a future generation." 57

so See Horton, Power of an Insured to Control the Proceevs of His Policies (I926) c. IV.

ot I Century Dictionary \& Cyciopedia (I914) 4I. Cited with approval in Thorn v. De Breteuil, 86 App. Div. 405, 83 N. Y. Supp. 849 (1903). 
Black's Law Dictionary states that,

"When an executor or other trustee masses the rents, dividends, and other income which he receives, treats it as a capital, invests it, makes a new capital of the income derived therefrom, invests that, and so on, he is said to accumulate the fund, and the capital and accrued income thus procured constitute accumulations." is

The test of an accumulation which is used most frequently by the courts is that found in Hascall o. King, ${ }^{59}$ wherein it is stated that the disposition of an estate which the rule aims to prevent is such as would deprive someone of the present enjoyment of each and every dollar of the net income and augment the value of the trust estate.

Prior to I8oI, when the Thellusson Act ${ }^{60}$ went into effect, there were no statutory restrictions on accumulations in AngloAmerican law; nor, indeed, had the limitation beyond which an accumulation was invalid at common law been decided. There were, to be sure, decisions to the effect that an accumulation not in excess of the permissible limitation under the rule against perpetuities was valid, ${ }^{61}$ but no case arose in which the estate was bound to vest within the permissible period under the rule against perpetuities, but which directed an accumulation beyond this period.

On July 21, I797, Peter Isaac Thellusson ${ }^{62}$ died, devising his property to trustees, to accumulate the income during the lives of his sons, grandsons, and grandsons' children living at his death, of whom there were seven and two en ventre sa mere, and then, at the death of the survivor, to transfer the property in three lots to the then living eldest male descendants of his three sons. The will was attacked by the Thellusson family on the ground, inter alia, that the accumulation was directed for too long a period, but

${ }^{2}$ Black, Law Dictionary (2d ed. I910) 19.

${ }^{{ }^{6}} 162$ N. Y. I34, I45, 56 N. E. 515, 518 (1900).

${ }^{\infty} 39$ \& 40 Gro. III, c. 98 (I800).

a See Duke of Bridgwater v. Egerton, 2 Ves. Sr. I22 (Eng. 1750); Bullock v. Stones, 2 Ves. Sr. 521 (Eng. I754); Thellusson v. Woodford, 4 Ves. 227 (Eng. 1798), it Ves. II2 (Eng. I805). See also 4 KeNT, Commentaries (I805) 285.

$\propto$ Thelusson is often spelled Thellusson, and sometimes Thelluson. 
the court declared itself powerless to hold the accumulation invalid at common law.

It should be noted in connection with the Thellusson case that the testator's residuary property at the date of his decease had an estimated value of $£ 600,000$. Mr. Morgan, of the Metropolitan Life Assurance Society of England, the best known actuary of his day, computed that the probable term of this accumulation was close to eighty years, and that, assuming it would increase at the current low rate of five per cent per annum, it would in seventyfive years, amount to $\mathfrak{f}_{23}, 299,6$ I I. ${ }^{63}$ The staggering proportions to which the corpus of this trust might grow, ${ }^{64}$ coupled with the lack of any restraint upon the right to accumulate, resulted in the passage of the Thellusson Act. ${ }^{6 \overline{5}}$ This act provides that accumulations are valid only:

(a) during the life of the grantor;

(b) for a term of twenty-one years from his death;

(c) during the minority of anyone who shall be living at the time of the grantor's death;

(d) during the minority of one who, under the trusts of the instrument, would, for the time being, if of full age, be entitled to the income.

These periods are alternative and only one may be chosen; two or more of them cannot be made consecutive periods for accumulation. ${ }^{66}$ Unlike limitations which violate the rule against perpetuities, a direction which violates the statute restraining accumulations is not entirely void, but is valid to the extent of such one of the four statutory periods as is operative, and is invalid only for the excess over such statutory period. ${ }^{67}$

See Hargrave, Treatise on tḥe Thelusson Acr (1842) 6, 7.

a* A friend of the author reports that one of the Thelusson descendants stated in his presence that the entire corpus of the trust was consumed by the litigation and that, in fact, Mr. Thelusson's descendants received nothing.

¿ Supra note 60; In re Lady Rosslyn's Trust, I6 Sim. 391 (Eng. I848).

${ }^{66}$ Wilson v. Wilson, I Sim. (N. S.) 288 (Eng. 185I) ; Jagger v. Jagger, 25 Ch. Div. 729 (1883); In re Errington, 76 L. T. 616 (1897).

${ }^{87}$ Griffiths v. Vere, 9 Ves. 127 (Eng. 1803) ; Langdon v. Simson, I2 Ves. 295 (Eng. 1806); Shaw v. Rhodes, I Myl. \& C. 135 (Eng. 1836). 
In $1828 \mathrm{New}$ York passed a statute making accumulations valid during a minority only, ${ }^{68}$ and then only if solely for the benefit of the minor involved. At present Illinois and Pennsylvania follow England. Arizona, Michigan, Minnesota and Wisconsin follow New York with reference to realty; Alabama is also in accord with New York as to realty, but, in addition, permits an accumulation of the rents and profits thereof which does not exceed ten years. ${ }^{69}$ Indiana and Montana follow New York with reference to personalty. ${ }^{70}$

The limit beyond which an accumulation may not be directed at common law has never been decided. There are cases holding that an accumulation which is not to exceed the permissible period under the rule against perpetuities is valid, ${ }^{71}$ but no case at common law has set a period beyond which a direction to accumulate is invalid. Where a court, in a jurisdiction lacking a statute restraining the right to accumulate, wishes to place a restraint on the right, in a case in which the estate is bound to vest within the period allowed under the rule against perpetuities, but which directs an accumulation beyond this period, it is submitted that the sound rule is to limit the right to the permissible period under the rule against perpetuities. ${ }^{2}$ The following alternatives are open to a court:

(I) It may declare the whole direction invalid under the rule against perpetuities; because, although there is no restraint on the power to alienate or the fact of alienability, the income is tied up for a longer period than is permitted by the rule, and the direction to accumulate is a condition precedent to the gift over. An argument against this construction is that it is a distortion of the rule which is, after all, concerned with the vesting of estates

\footnotetext{
${ }^{63}$ See supra note 55 for references to the New York law.

${ }^{\text {eq }}$ It was held in Campbell v. Weakley, 121 Ala. 64, 25 So. 694 (I898) that an agreement to accumulate for a longer period than ten years is void $a b$ initio. states.

${ }^{70}$ See appendix for a chart showing the law of accumulations in the various

TSee cases cited supra note 61.

To Andrews v. Lincoln, 95 Me. 54r, 50 Atl. 898 (IgOI) has sometimes been cited for this proposition, but the case is not in point. That case involves a trust with a direction to accumulate for thirty years. The court said the direction violated the rule against perpetuities, and therefore declared the whole invalid.
} 
and the probability of their alienation, and not with the tying up of income. A possible answer to this is that the vesting of property without its fruits gives the person in whom it is vested an emasculated estate; and the vesting of a bare estate without its profits is so negligible as to contravene the spirit, if not the letter, of the rule. Construction (I), however, would entirely defeat the creator's intention, and courts tend to uphold trusts as much as possible.

(2) It may cut the accumulation down to the permissible period of the rule against perpetuities and sustain the rest, thus doing at common law what other jurisdictions have accomplished by statutory enactment.

(3) It may apply some arbitrary period, other than that of the rule against perpetuities, as a yardstick for measuring the valid limitation of an accumulation.

(4) It may apply no period at all, and thereby place no judicial restrictions whatsoever on accumulations.

The question whether a funded insurance trust is an accumulation, within the meaning of the rules and statutes relating thereto, is of importance in only a few states. The policy will generally be on the life of the settlor; and therefore the accumulation will be limited to last not longer than the period permitted under the rule against perpetuities or under the Thellusson Act. Only in those states in which settlements of property which involve an accumulation of the income may not last longer than the minority of the person benefited does the problem become acute. As has been indicated, these states are Alabama, Arizona, California, Indiana, Michigan, Minnesota, Montana, New York, North Dakota, South Dakota, and Wisconsin. New York has solved the problem by a statutory declaration in its Personal Property Law that such trusts do not involve an accumulation. It is still a question whether the statute applies to trusts of realty.

This question is not entirely a new one in the courts, for it has been litigated three times in England, once in Scotland, and once in New York. Each of these cases, however, involves a testamentary direction by a testator to purchase insurance with the income of his estate, rather than a direction by a living settlor 
to use the income of a given fund to purchase insurance. The same arguments are applicable, however, to funded insurance trusts as to the testamentary directions in the cases which we are about to consider. Bassil $v$. Lister ${ }^{73}$ was a case in which a testator directed his executors to pay, out of the income of his property, the premiums on policies of insurance on the lives of two of his sons. The question was whether this direction was valid or whether it was an accumulation within the meaning of the Thelluson Act, and therefore only valid for a period of twentyone years. The court held the direction not to be an accumulation. The reasons assigned by the court for reaching this result were:

(I) That the Thellusson Act was aimed against the accumulation of rents and profits as such ${ }^{74}$ ( $i$.e., by the addition of the income directly to the corpus), and not to an accumulation which is incidental to the real purpose of the trust, the purchase of insurance.

(2) That the resulting accumulations cannot be traced to any particular premiums, ${ }^{75}$ the whole fund being productively employed by the insurance company.

(3) That what the estate would receive back was not the accumulation of the income, but the realization of a contract right.

Other arguments which have subsequently been made in support of this result have been:

(4) That "the proceeds of the policy may well go to persons other than the ultimate beneficiaries of the trust", there being no augmentation of the corpus.

(5) That the policy is merely a device for preserving the property, and not for increasing it. ${ }^{i 6}$

(6) That insurance policies are a necessity, and that there is therefore no deprivation of present enjoyment. ${ }^{i 7}$

(7) That the letter of the statutes has not always been followed, and insurance trusts are sufficiently desirable to warrant another exception to the statute.

\footnotetext{
"Sitpra note 2.

"Ibid. 182, 183 .

Ibid. 183 .

ig (1923) 37 Trust Companies 695.

"In re Hartman's Estate, supra note 9.
} 
The first argument, that it is not an accumulation of income as such, opens the question how the Thellusson Act should be construed. Since it is a restriction on the common law, must it be strictly construed? Vice-Chancellor Sir J. G. Turner, in Bassil $v$. Lister, would have limited it to its facts. But the application of the statute has not been limited to the facts of the case which precipitated its passage ${ }^{78}$ its terms are general and comprehensive, and its application has been wide. Any case which fits the description of an accumulation should be governed by the restrictions prescribed in the statute. Unless, then, we can find something economically or socially distinguishable between insurance trusts and ordinary directions to accumulate, we are forced to apply the statute.

The second argument, that there is no hoarding of the income and that it is impossible to trace the accumulations from any particular premium, could have been made in favor of the direction in Thellusson $v$. Woodford, ${ }^{79}$ yet that is the very case which precipitated the passage of the Thellusson Act. Peter Isaac Thellusson did not direct that the income from the corpus of his estate should be earmarked and kept separate, in a vault, for the ultimate beneficiaries; he directed that the income should be reinvested in other real estate, which is undeniably similar to the purpose to which the premiums in the hands of the insurance company are put. Furthermore, insurance policies had no cash surrender value at the time of the Bassil v. Lister litigation, but today, with the exception of term insurance, they have such a cash value. Hence, with each succeeding payment to the insurance company, we are able to trace the result of the accumulation.

The third argument was also assigned as the basis of the decision in Cathcart's Trustees $v$. Heneage's Trustees, ${ }^{80}$ where the testatrix empowered her trustees "if they saw cause, to make insurance on the life of her nephew", and to pay the premiums out of the income of the testatrix's estate. They paid premiums for more than thirty-seven years, the sum realized on the policy being

${ }^{2 s}$ For a geod account of the act's early treatment by the courts, see HARCRAVE, op. cit. supra note 63 .

Tupra note 6I.

${ }^{80}$ 1o Sess. Cas. 1205 (Scot. 1883). 
less than the premiums paid. It was held that there was no accumulation in that case. The court argued that the proceeds which fall to the estate "do not arise out of accumulation, but out of contract", and because of this fact the device was not invalid. Admitting that this is true, what difference should it make? Indirect accumulations are no more to be countenanced than direct ones. ${ }^{81}$ There is here an augmentation of the corpus and that spells out an accumulation within the technical meaning of the word. ${ }^{82}$

The fourth argument, basing the validity of the device on the fact that the accumulated income may go to someone other than the recipient of the corpus, is invalidated by Matter of Sands, ${ }^{83}$ where the testator provided that his business should be continued and the profits thereof paid to his executors until the majority of his youngest child, the segregated profits then to be divided among his wife and children, the "fee" of the business passing to his residuary estate. The court unhesitatingly called this an invalid accumulation, irrespective of the fact that the "fee" of the business was not augmented by the accumulation of income in the hands of the executors for persons other than his residuary legatees; saying that, since it was an accumulation which was not wholly for the benefit of minors, it was invalid. The fact that the amount realized was less than the sum of the premiums paid out probably influenced the court in Cathcart's Trustees $v$. Heneage's Trustees, although it seems logically irrelevant.

The fifth argument is based on cases in which the income was used to keep the corpus from depreciating in value. In Re Gardiner $^{84}$ the testator directed that a yearly sum be set aside, out of leaseholds which had thirty-three years to run from the date of the testator's death, to pay the premiums on a policy of insurance to

${ }^{81}$ See Penniman v. Howard, 71 Misc. 598, I28 N. Y. Supp. 9ro (I9II); Thorn v. De Breteuil, supra note 57 , where the court speaks of contravening the "letter or spirit of the statute". "The same attitude is seen in the "implied direction to accumulate cases"; see, for instance, In re Neel's Estatc, $252 \mathrm{~Pa}$. 394, 97 Atl. 502 (1916).

${ }^{8} C f$. Hascall v. King, sutpra note 59 .

$\$$ I Con. 259, 3 N. Y. Supp. 67 (I889).

sigor] I Ch. 697 . 
secure the replacement, at the end of the term, of the capital that would be lost through the expiration of the leaseholds. This was held not to be an invalid direction to accumulate. While the principle that the income of property may be used to preserve the property is unquestioned, ${ }^{85}$ it is not applicable to this case. The cases invoking the principle are cases in which there was an unquestionably valid direction of income, the expenditures for preservation being merely incidental thereto, whereas in our case the entire expenditure is for preservation. Furthermore, in these cases the expenditures were necessary, all other things being equal, to make the corpus of approximately the same value when it finally vested as it was at the creation of the trust; but in the case under discussion, far from preserving, it is being used as a means of creating an estate-augmenting the principal.

The sixth argument was made in the New York case of In re Hartman's Estate, ${ }^{86}$ where a testator created a trust, directing his executors to set aside an annuity sufficient to pay the premiums on a policy insuring the life of his son-in-law. The question was whether such a trust was void as creating an accumulation within the meaning of the New York statute, and the court held that it was not an invalid accumulation. Surrogate O'Brien, in attempting to show that there was no deprivation of present enjoyment of the net income, said :

"So far as present enjoyment of the fund is concerned, the present benefit includes, with all those who in one way or another participate, the beneficiary of the insurance, testator's daughter. Life insurance has come to be a vital factor in the life of our people. The present comfort, solace and protection of an insurance policy in the household is properly placed close to, if not among, the necessaries of life, and is secured with a sense of satisfaction and of duty fulfilled by the many as they would make sure of the coats on their dependents' backs or the roofs over their heads. What a source of present comfort this insurance is here to one who has been cut off in every other respect from participation in her father's substantial estate! Viewed in a practical light, this insurance

ss Vine v. Raleigh, [1891] 2 Ch. 13; In re Nesmith, 140 N. Y. 609, 35 N. E. 942 (1894); In re Hurlbatt, [1910] 2 Ch. 553.

${ }^{8}$ Supra note 9. 
means just so much of the expenses of the household of the insured and beneficiary covered, as they might themselves otherwise expend on insurance." $8 \bar{\tau}$

The most patent argument against the learned surrogate's position is that "present comfort, solace, and protection" is not money. The test which he is attempting to satisfy is whether or not there is a deprivation of enjoyment of income, and by that is meant a deprivation of cash. Furthermore, the statement that insurance (particularly life insurance, with which we are mainly concerned) is "properly placed close to, if not among, the necessaries of life" is open to grave doubts. This, coupled with the fact that the settlor's direction to purchase insurance results in an augmentation of the corpus, renders the argument open to serious attack.

The surrogate's argument would seem to apply just as well to the case of a savings account into which the settlor ordered his trustee to put some of the income; for savings are almost as much a necessity, and serve almost the same purposes, as insurance. ${ }^{s s}$

The last argument, and the one which is probably the strongest, is that, since the letter of the statutes against accumulations has not always been followed, and since funded insurance trusts seem so desirable socially, they should constitute another exception to the statutes. New York has accomplished this result by statute.

For instance, accumulations resulting from an unforeseeable inability to devote the entire income to an otherwise valid use directed by the settlor have been held valid on the ground that

${ }^{87}$ Ibid. 866, 215 N. Y. Supp. at 806.

s This reasoning of Surrogate O'Brien may lead to undesirable, if not unsound, results. Thus in In re Hartman's Estate, I35 Misc. 428, $232 \mathrm{~N}$. Y. Supp. 672 (1929) it was decided that the testator's son-in-law, whose life was insured under the terms of the Hartman will, should be charged with the transfer tax on the annuity necessary annually to pay the premiums, since he was the insured and received the benefits of the provision in the will. Onc can imagine the alleged enjoyer pawning his possessions to pay the transfer tax on a benefit which will some day accrue to persons other than himself. It is submitted the learned surrogate would not have been adopting a position inconsistent with that taken by him on the accumulations point, had he taxed the transfer to the trustee rather than the insured. One's inclination is to say that the beneficiaries of the proceeds of the policy should pay the tax; the strongest legal position, so far as consistency is concerned, would be to tax the trustee; to tax the insured seems surprising. Cf. In re Haedrich's Estate, $236 \mathrm{~N}$. Y. Supp. 395 (I929). 
they are purely accidental; ${ }^{89}$ and, similarly, a direction to keep the property in repair in order to prevent its depreciation in value has been upheld on the ground that new rights, privileges, or immunities are not being created, when in fact they are. ${ }^{90}$ Since this is true, and since every court that has passed on the validity of a testamentary direction to purchase insurance with the income of an estate $" 1$ has evidenced its desire to uphold the validity of a direction to purchase insurance, by holding that it does not contemplate an invalid accumulation, despite able argument by counsel and text writers ${ }^{92}$ for the opposite view, we may expect courts to continue deciding the same way. The difficulty with this argument is that the cases are old, and, with the exception of In re Hartman's Estate and Cathcart's Trustees v. Heneage's Trustees, are English cases. It may well be that the English cases have established the law there, but they would only be persuasive authority, at best, in an American jurisdiction. This lack of American authority, coupled with the fact that the soundness of the decided cases is highly questionable, does not lend much comfort, by way of predictability, to the creator of an insurance trust.

The Thellusson Act provides that. "the Rents, Issues, Profits, and Produce of such Property so directed to be accumulated, shall, so long as the same shall be directed to be accumulated contrary to the Provisions of this Act, go to and be received by such Person or Persons as would have been entitled thereto if such Accumulation had not been directed". ${ }^{93}$ There was a tendency on the part of the English courts in the early cases to argue that the accumulation is a condition precedent to the gift over of the corpus and therefore the trust is entirely invalid, since the settlor has said that the gift shall vest at too remote a time, and the court cannot sub-

"Eberley's Appeal, 1 10 Pa. 95, I Atl. 330 (1895); In re Kohler, 193 App. Div. 8, I83 N. Y. Supp. 550 (I920).

${ }^{\circ}$ For example, see Vine v. Raleigh, supra note 85 , where income was expended to improve the condition of buildings, thus keeping them "in good, habitable repair", and In re Nesmith, supra note 85 , where income was used to build a shed at a cost of \$12,000.

${ }^{91}$ In re Vaughn, I8 W. N. 89 (Eng. 1883) was a case in which a testator created a trust to pay premiums on a policy insuring the lives of his sons, and the court held that this was not an invalid direction to accumulate.

82 I JARMraN, Wills (4th ed. I88I) 316, 317, (6th ed. 1910) 391 ct seq.

${ }^{2}$ Strpra note 60. 
stitute a shorter time. ${ }^{94}$ But courts have always tended to uphold trusts as much as possible and construe limitations as vested. These facts, in addition to the words of the act, have resulted in the determination, in the more recent cases, that only the period of invalid accumulation is bad, and the released income thus goes to the settlor or his estate (heirs, next of kin, or residuary legatees) until the time when the invalid accumulation was to end. ${ }^{95}$

In a jurisdiction having a statute restraining the right to accumulate, where there is a direction that the released income shall go to the "presumptive holder of the next eventual estate", 96 the released income goes to the donee of the corpus. ${ }^{97}$

Typical of such statutes is that of California, ${ }^{98}$ which reads as follows:

"When, in consequence of a valid limitation of a future interest, there is a suspension of the power of alienation, or of the ownership during the continuation of which the income is undisposed of, and no valid direction for its accumulation is given, such income belongs to the persons presumptively entitled to the next eventual interest."

It should be noted that in orcier for the statute to apply there must be (I) a suspension of the power of alienation or of the ownership and (2) a person presumptively entitled to the next eventual interest. If either of these is lacking, the statute does not apply, and the released income passes by intestacy. ${ }^{99}$

0: Vawdry v. Geddes, I Russ. \& M. 203 (Eng. I830) ; Curtis v. Lukin, 5 Beav. I47 (Eng. I842); Scarisbrick v. Skelmersdale, I7 Sim. I87 (Eng. I850). 2 Ch. 4 .

${ }^{95}$ Oddie v. Brown, 4 De G. F. \& J. I79 (Eng. I859); In re Wood [I904]

${ }^{90}$ This applies to all American jurisdictions which have enacted statutes with reference to invalid accumulations, with the exception of Illinois and Pennsylvania, which follow England, and Alabama, Arizona and Indiana, which have no provision directing the fate of the released income. See appendix.

${ }^{\pi}$ The provision concerning the presumptive holder of the next eventual estate, though found in Section 63 of the N. Y. Real Property Law, has been applied to income from personalty as well. In re Harteau, 204 N. Y. 292, 97 N. E. 726 (19I2). But in Michigan and Minnesota, where the statutes restraining the right to accumulate only affect the right to accumulate income from realty, and not personalty, the "presumptive holder of the next estate" provisions have been held inapplicable to the income earned by personalty. Toms v. Williams, 4I Mich. 552, 2 N. W. 814 (1879) ; Congdon v. Congdon, I60 Minn. 343,200 N. W. 76 (I924).

${ }^{28}$ Cal. Crv. Code (Deering, 1923) § 733.

U. S. Trust Co. v. Soher, 178 N. Y. 442, 70 N. E. 970 (1904). 
There has always been a tendency on the part of the courts to sustain as much of a trust as is valid, deleting only the invalid portions. This has been done, without exception, in hundreds of cases involving testamentary trusts, the gift over being upheld when there was an invalid direction to accumulate income. But, in the only cases of living trusts which can be found in the reports, in which there is an invalid direction to accumulate income with a valid gift over, the courts have declared the whole trust invalid. Thus Mann-Vynne v. Equitable Trust Company ${ }^{100}$ was a case in which the settlor directed that the trustee set aside enough of the rents and profits each year to amortize a mortgage plus interest, to pay off a note, and to pay what remained to the settlor; the court, on the basis of the invalid direction to accumulate, declared the whole trust void, despite the fact that the gift over was perfectly valid. Herzig $v$. Herzig ${ }^{101}$ was a similar case of a living trust in which the court reached the same conclusion.

Although the words of the statute would seem to apply with equal force to living trusts and to testamentary trusts, there is a strong argument in favor of refusing to apply it to the former. In the case of a testamentary trust the testator, having made an invalid disposition of the income, cannot redispose of it, since he is dead. Rather than declare the whole trust invalid, the court upholds as much thereof as is possible. On the other hand, where . the creator of the trust is still alive, the court prefers to return the corpus and permit him to redispose of it in its entirety, rather than to apply an arbitrary rule as to the income thereof. Furthermore, it is submitted that the principle invoked by the courts in declaring the whole disposition invalid in the case of living trusts-namely, its inability to separate the valid provisions from the invalid-are peculiarly applicable to the typical funded insurance trust. The settlor's primary intention in creating an insurance trust is to provide income with which to pay premiums on life insurance and the gift over on the death of the insured is only of secondary importance. Having failed to provide a valid means of paying these premiums, the entire trust should fall, rather than confer a bene-

${ }^{100} 201$ App. Div. I49, I94 N. Y. Supp. 50 (1922).

${ }^{101} 140$ App. Div. 514, I25 N. Y. Supp. 402 (1910). 
fit, not only with the corpus but with the income as well, upon those whose bounty is secondary.

In Alabama, Arizona and Indiana, where there are statutes restraining the right to accumulate, but no statutory direction of the released income, it passes to the settlor. If the latter is dead, the income from realty passes to his heirs and the income from personalty goes to his next of kin. If there is a residuary clause in the settlor's will, the residuary legatees are entitled to the income. ${ }^{102}$

\section{Tax Aspects of Insurance Trusts: The Taxation of the Proceeds of Insurance Policies Under Federal and State Inheritance Taxes}

The Federal Estate Tax, ${ }^{103}$ like all inheritance taxes, rests on

${ }^{102}$ But $c f$. Campbell v. Weakley, supra note 69.

${ }_{103}$ The relevant provisions of the Revenue Act of I926, 44 Stat. 69, 26 U. S. C. $\S$ I09I et seq. (Supp. 1928) (unrepealed by the Revenue Act of 1928) are as follows:

"SEC. 30I (a) In lieu of the tax imposed by Title III of the Revenue Act of 1924, a tax equal to the sum of the following percentages of the value of the net estate (determined as provided in section 303) is hereby imposed upon the transfer of the net estate of every decedent dying after the cnactment of this act, whether a resident or nonresident of the United States;

I per centum of the amount of the net estate not in excess of $\$ 50,000$; (graduated rates follow, reaching 20 per centum of the amount by which the net estate exceeds $\$ 10,000,000)$. . .

"SEC. 302. The value of the gross estate of the decedent shall be determined by including the value at the time of his death of all property, real or personal, tangible or intangible, wherever situated-

(c) To the extent of any interest therein of which the decedent has at any time made a transfer, by trust or otherwise, in contemplation of or intended to take effect in possession or enjoyment at or after his death, except in case of a bona fide sale . . . Where within two years prior to his death .. . and without such a consideration the decedent has made a transfer... of any of his property ... . and the value . . of the property . . . transferred to any one person is in excess of $\$ 5000$, then, to the extent of such excess, such transfer . . . shall be deemed and held to have been made in contemplation of death.

(d) To the extent of any interest therein of which the decedent has at any time made a transfer, by trust or otherwise, where the enjoyment thereof was subject at the date of his death to any change through the exercise of a power, either by the decedent alone or in conjunction with any person, to alter, amend, or revoke, or where the decedent relinquished any such power in contemplation of his death, except in case of a bona fide sale

(g) 'To the extent of the amount recervable by the cxecutor as insurance under policies taken out by the decedent upon his own life; and to the extent of the excess over $\$ 40,000$ of the amount receivable by all other 
"the principle that death is the generating source from which the particular taxing power takes its being". ${ }^{10 *}$

The peculiar feature of the tax is that it is measured by the net estate of the decedent (after an $\$ 100,000$ exemption) and, in the absence of express provision in the will, ${ }^{105}$ the entire burden falls on the residuary legatee. ${ }^{100}$ The tax is, therefore, usually described as a tax "not (on) the interest to which some person succeeds on a death, but the interest which ceased by reason of the death", ${ }^{10 \pi}$ as opposed to state transfer taxes, which are generally described as taxes on the right of the beneficiary to take property on the death of another, ${ }^{10 S}$ since they are measured by

beneficiaries as insurance under policies taken out by the decedent upon his own life...

"SEc. 303. For the purpose of the tax the value of the net estate shall be determined-

(a) In the case of a resident, by deducting from the value of the gross estate ....

(4) An exemption of $\$ 100,000$.

"SEC. 314. (b) . . . If any part of the gross estate consists of proceeds of nolicies of insurance upon the life of the decedent receivable by a beneficiary other than the executor, the executor shall be entitled to recover from such beneficiary such portion of the total tax paid as the proceeds, in excess of $\$ 40,000$, of stich policies bear to the net estate. If there is more than one such beneficiary the executor shall be entitled to recover from such beneficiaries in the same ratio."

Section 315 makes the tax a lien for ten years upon all property included in the gross estate. If the tax is not paid, any beneficiary or legatee can be held liable. Section 314 gives one who has paid more than he should a crossaction against those equally, or more immediately, liable.

Section 303 (e): "The amount receivable as insurance upon the life of a nonresident within the United States."

U. S. Treas. Reg. 70, art. 25: “The term 'insurance' refers to life insurance of every description, including death benefits paid by fraternal beneficial societies, operating under the lodge system."

${ }^{10 k}$ Knowiton v. Moore, 178 U. S. 41, 56, 20 Sup. Ct. 747, 753 (1900).

${ }^{105}$ Brown's Estate v. Hoge, I98 Iowa 373, 199 N. W. 320 (1924); Matter of Oakes, 248 N. Y. 280,162 N. E. 79 (I928).

${ }^{100}$ The burden falls in general wherever the state law puts it. Edwards v. Slocum, 264 U. S. 6I, 44 Sup. Ct. 293 (1924). As a rule this means that it falls on the residuary legatee. Plunkett $v$. Old Colony Trust Co., 233 Mass. 47I, 124 N. E. 265 (I919); Thompson v. Union \& Merc. Trust Co., 164 Ark. 4II, 262 S. W. 324 (1924); Y. M. C. A. v. Davis, 264 U. S. 47,44 Sup. Ct. $29 \mathrm{I}$ (I924); Farmers' Loan and Trust Co. v. Winthrop, $238 \mathrm{~N}$. Y. $488,144 \mathrm{~N}$. E. 769 (1924), certiorari denied in 266 U. S. 633,45 Sup. Ct. 225 (1925). Contra: Fuller v. Gale, 78 N. H. 544, 103 Atl. 308 (1918) (apportioning tax among all legatees).

${ }_{10:}$ Edwards v. Slocum, supra note 124 , at 63,44 Sup. Ct. at 293 ; cf. Succession of Gheens, $148 \mathrm{La}$. 1017, 88 So. 253 (192 I).

${ }^{108}$ Magoun v. Illinois Trust Co., I70 U. S. 283, 288. I8 Sup. Ct. 594 ( I898). 
the size of the share taken by each beneficiary, and each one pays a tax on his own share. ${ }^{109}$ Thus an estate of $\$ I, 000,000$ divided equally among ten beneficiaries will be taxed by the federal government as an estate of $\$ 1,000,000$, and not as ten estates of $\$ 100,000$ each; while the state will tax it as the latter. The federal estate tax on a net estate of $\$ 100,000$ is $\$ 1,500$. On a net estate of $\$ 1,000,000$ the tax is $\$ 48,500$, over thirty times as much.

If the gross estate is less than $\$ 100,000$, there will be no federal estate tax. The tax is determined on the basis of the net estate, which is the gross estate less certain specified deductions, including a $\$ 100,000$ exemption in the case of residents of the United States.

It should be noted that the insurance provisions of the act only apply to policies taken out on the decedent's life. Hence, if a man wishes to obtain the advantages of an investment trust and effect a saving in taxes, he may do this by taking out a policy on the life of his wife. If an unfunded trust is created with respect to the proceeds of the policy, these proceeds will not be subject to the estate tax as a part of the husband's estate, since they are not proceeds of a policy covering the life of the decedent, and they will not be subject to the tax as a part of the wife's estate, since she did not pay the premiums either directly or indirectly ${ }^{110}$ and accordingly cannot be held to have taken out the policy.

The statute expressly taxes policies payable to one's estate or to one's executor, where they were taken out by the insured. ${ }^{111}$ This branch of the statute also covers insurance payable to a trustee for the purpose of paying death taxes and administration expenses, so that there is no $\$ 40,000$ exemption on such policiès.

The Treasury regulations provide that:

"It includes insurance taken out to provide funds to meet the estate tax and any other taxes or charges which are enforceable against the estate. The manner in which the

${ }^{10}$ See, for example, N. Y. TAx LAW (1928) art. 10, § 220 et seq., N. Y. Cons. Laws Ann. (Supp. I928) 997.

${ }^{100}$ U. S. Treas. Reg. 70, art. 25.

III In Mimnaugh v. U. S., $66 \mathrm{Ct}$. Cl. 4 II (1928) the $19 \mathrm{I} 8$ tax (not expressly retroactive) was held applicable to policies taken out before 1918 , payable to the insured's estate. 
policy is drawn is immaterial so long as there is an obligation, legally binding upon the beneficiary, to use the proceeds in payment of such taxes or charges." 112

As to policies payable to third parties, the statute ${ }^{113}$ is clear on its face. It taxes all policies in excess of $\$ 40,000$ taken out by the decedent on his own life. The only possible question is as to the constitutionality of the tax. It was held constitutional as to policies in which the insured retained a power to change the beneficiary, in Chase National Bank $v$. United States. ${ }^{114}$ This case settles finally the ordinary case of an insurance policy, since policies are generally revocable.

However, in a funded insurance trust it would not be surprising to have both the trust and the policy irrevocable; ${ }^{115}$ and the ordinary rights and privileges (borrowing, surrendering, endowment rights, dividends, etc.) may be given to the trustees or to the beneficiary. ${ }^{116}$ The taxation of irrevocable policies' is, therefore, of some importance, especially if the conclusion is that they are not taxable. Let us consider the taxability of irrevocable policies, first per se and then as part of an insurance trust.

The argument against the validity of a tax on an irrevocable policy is based on two grounds: That the tax is a direct tax and unconstitutional because unapportioned, in violation of the Constitution; ${ }^{117}$ or that the tax is so arbitrary and capricious as to violate the Fifth Amendment (the due process clause).

The first argument is substantially as follows. ${ }^{118}$ It is first urged that the very nature of the insurance agreement makes the

120 Supra note I10, art. 26.

${ }^{113}$ Supra note 103, \& 302 (g).

${ }^{114} 278$ U. S. 327,49 Sup. Ct. 120 (1929). Policies taken out in 1922, payable to the insured's wife and reserving a power to change the beneficiary, were held taxable under the Revenue Act of I92I.

${ }^{115}$ The term "irrevocable" will be used as a shorthand expression for the absence of a reservation of the power to change beneficiaries in policies.

${ }^{116}$ Where the policy is revocable, but the trust is not, a peculiar problem arises as to which, if either, is to govern. Staples v. Murray, I24 Kan. 730, 262 Pac. 558 (1928).

${ }^{11}$ U. S. Constitution, Art. I, \& 9, CL. 4.

${ }^{118}$ Frick \& Lewellyn, 298 Fed. 803 (W. D. Pa. 1924) (holding the tax invalid as to revocable and irrevocable policies), aff'd on different grounds in 268 U. S. 238,45 Sup. Ct. 487 (1925). 
tax invalid. The insured disposes of no property in the sense of testamentary or inter vivos gifts. He merely contracts with the insurance company that in return for the payment of periodical sums the company will pay, on his death, a definite sum to a designated beneficiary. The beneficiary's interest in the contract vests immediately. There is no taxable transfer of property at the time of death, as there is in the case of the revocable policy where it is the termination of the power of revocation that is taxed. ${ }^{119}$ The tax, therefore, is either imposed on the beneficiary because he is the owner of the proceeds or the chose in action, or it is a tax on the right to give property inter vivos. In either case it is a direct tax.

The second argument is based on the due process clause. It is argued that the estate tax, as a tax which the executor must pay, ${ }^{120}$ is unreasonable, since the proceeds of policies which are taxed belong to the beneficiary and not to the insured. ${ }^{121}$ The right of reimbursement ${ }^{122}$ is surely not an adequate safeguard, for the beneficiary may be insolvent. ${ }^{123}$ As a tax on the beneficiary it is bad, because he pays a rate based on the size of the testator's estate. ${ }^{124}$ This is unreasonable, because the proceeds are not in any way the decedent's. ${ }^{125}$ The tax is likewise an unfair discrimination against the beneficiary of a policy on the life of one leaving a large estate. Two beneficiaries, receiving $\$ 140,000$ each, might pay a greatly different tax. If the insured left a net estate of $\$ 19,000,000$, the beneficiary would pay a tax of approximately $\$ 10,000$; whereas if the insured left no other

\footnotetext{
${ }^{270}$ Stone, J., in Chase National Bank v. U. S., supra note II4 at 338, 49 Sup. Ct. at 129.

${ }^{100}$ Supra note 103, § 305 (a).

12 "Jt may be doubted by some, aside from express constitutional restrictions, whether the taxation by Congress of the property of one person, accompanied with an arbitrary provision that the rate of tax shall be fixed with reference to the sum of the property of another ... would not transcend the limitations arising from those fundamental conceptions of free government which underlie all constitutional systems." Knowlton v. Moore, supra note 104, at 77,20 Sup. Ct. at 762 .

${ }^{202}$ Supra note 122, § 3 I4 (b).

203 Furthermore, including the policies in the estate may make higher brackets applicable, and so raise the tax on the entire estate.

${ }^{224}$ Supra note I2I.

${ }^{125}$ See the discussion as to the directness of the tax, supra p. 376 et seq.
} 
property the beneficiary would be free from taxation altogether. ${ }^{120}$

The answer to the first argument would seem to be that life insurance is a form of property like a savings bank deposit, being traceable to the premiums, and not a bare contract right; ${ }^{12 \pi}$ and that the vested character of a gift does not necessarily defeat the estate tax. ${ }^{128}$ Many gifts have been held taxable under the estate tax as gifts to take effect at death, where the interests of the beneficiaries were vested inter vivos. Where $S$ conveys to $T$ in trust for $S$ for life, remainder to $X$, the trust has been taxed. ${ }^{129}$ Only three types of taxes have ever been called direct by the Supreme Court; poll taxes, income taxes, and property taxes, which, in form, tax a res. ${ }^{130}$

It would seem that, in the absence of a binding and rigid test as to what constitutes a direct tax, the tax on policies should, and will, be held valid. The fact that the proceeds are the offspring of the premiums would make the tax on the proceeds, if not an excise on the transfer at death, an excise on the privilege of making the inter vivos gift. ${ }^{131}$

\footnotetext{
${ }^{100} \$ 40,000$ deduction on the policies; $\$ 100,000$ exemption on all estates. Supra note 103, $\$ \S 303,314$ (b).

${ }^{127}$ Chase National Bank v. U. S., supra note II4, at 337,49 Sup. Ct. at I28. "Obviously, the word 'transfer' in the statute, or the privilege which may constitutionally be taxed, cannot be taken in such a restricted sense as to refer only to the passing of particular items of property directly from the decedent to the transferee. It must, we think, at least include the transfer of property procured through expenditures by the decedent with the purpose, effected at his death, of having it pass to another. . . . It is of some significance also that by the local law applicable to the insurer and the insured in this case, a beneficiary's rights in the policy and its proceeds are deemed to be the proceeds of the premiums expended by the insured and as such recoverable in full by one having an equitable claim attaching to the premiums. Holmes v. Gilman, I38 N. Y. $369 . "$

${ }^{223}$ Saltonstall v. Saltonstall, 276 U. S, 260, 271, 48 Sup. Ct. 225, 227 (1928).

${ }^{109}$ Safe Deposit \& Trust Co. v. Tait, 295 Fed. 429 (D. C. Md. 1923); Cleveland Trust Co. v. Routzahn, 7 F. (2d) 483 (N. D. Ohio I925), rev'd on different grounds in 22 F. (2d) I009 (C. C. A. 6th, I927); McCaughn v. Girard Trust Co., II F. (2d) 520 (C. C. A. 3d, I926); May v. Heiner, 25 F. (2d) 1004 (W. D. Pa I928); Nichols v. Bradley, 27 F. (2d) 47 (C. C. A. Ist, 1928). Contra: Miller v. Ú. S., 62 Ct. Cl. 404 (1926); Arnold v. U. S., 62 Ct. Cl. 439 (1926); Frew v. Bowers, 12 F. (2d) 625 (C. C. A. 2d, 1926), dismissed, 275 U. S. 578, 48 Sup. Ct. 22 (I927); Carnill v. McCaughn, 30 F. (2d) 696 (E. D. Pa. I929).

${ }^{120}$ Note (1926) 26 CoL. L. Rev. 852.

${ }^{131}$ The gift tax, now repealed, was held constitutional in Bromley v. McCaughn, 26 F. (2d) 380 (E. D. Pa. 1928). In Blodgett v. Holden, 275 U. S. I42, 276 U. S. 594, 48 Sup. Ct. I05 (C. C. A. 6th, 1928) and Untermeyer v. Anderson, 276 U. S. 440,48 Sup. Ct. 353 (C. C. A. 2 d, I928) the gift tax was
} 
The second argument would seem to be just as applicable to the case of a revocable policy, yet the tax as applied to such policies was expressly held constitutional in Chase National Bank $v$. United States. ${ }^{132}$ The general counsel of the Internal Revenue Department has expressly ruled that insurance policies, though assigned in contemplation of, or to take effect on, death, do not fall within Section 302 (c), ${ }^{133}$ the section taxing such gifts.

\section{A. State Estate Taxes}

The Revenue Act of 1926 provides:

"The tax imposed by this section shall be credited with the amount of any estate, inheritance, legacy, or succession taxes actually paid to any State or Territory of the District of Columbia, in respect of any property included in the gross estate. The credit allowed by this subdivision shall not exceed $80 \%$ of the tax imposed by this section, and shall include only such taxes as were actually paid and credit therefor claimed within three years after the filing of the return required by Section 304." 134

This section allows the estate of a decedent to deduct all state inheritance taxes up to 80 per cent of the tax imposed by the rates in Section 30I (a). The result of this provision was the enactment of state estate taxes designed expressly to cover this slack. Sixteen states have enacted such estate taxes. ${ }^{135}$ Some, like New

held unconstitutional only as to retroactivity-there was no doubt expressed in the opinions as to its general validity. The Supreme Court, in Bromley v. McCaughn, decided Nov. 25, I929, held the gift tax constitutional.

Sispra note II4.

${ }^{23 s} \mathrm{VI} \rightarrow \mathrm{I}$ Cum. Bull. 3Ir8.

134 Section 30I (b) $;$ stipjä nòte 122.

135 In Montana and Coloratio the tax applies only to estates over $\$ 1,000,000$; in Rhode Island, $\$ 250,000 ;-$ in New York, $\$ 200,000$, or where the estate exceeds $\$ 100,000$ and includes property transferred contingently, etc. N. Y. Laws I909, c. $62, \S 2492$.

In Mississippi and Tennessee policies over $\$ 20,000$ are included.

In Colorado, Pennsylvania, Rhode Island, and Virginia the tax is expressly to be Lorne by all legatees and beneficiaries proportionately. Only in New York is the tax on policies expressly made payable by the beneficiaries.

In Mississippi and Georgia the estate tax is the only inheritance tax.

In Hagood v. Doughton, I95 N. C. 8II, I43 S. E. 84I (I928) the North Carolina estate tax was construed as being independent of any state inheritance taxes; its reference to the federal tax being merely for the purpose of specifying rates, etc. This would seem to make the North Carolina tax, at any rate, independent of the existence of the Federal Estate Tax. 
York, ${ }^{136}$ have enacted miniature replicas of the federal act, with a rate schedule four-fifths of the federal rates and a provision for crediting other state inheritance taxes. Others, like California, ${ }^{137}$ take up the slack expressly in general terms. The federal rulings will no doubt be followed in all these states. ${ }^{138}$

\section{B. State Transfer Taxes}

The state transfer taxes are generally considered as in their nature different from the estate tax. ${ }^{139}$ However, except for the method of computation and the difference in the person who bears the burden of the tax in the absence of express provision in the will, ${ }^{140}$ there is no real distinction. As was well said by Van Devanter, J., in Frick v. Pennsylvania: 1+1 "While the Federal tax is called an estate tax, and the state tax is called a transfer tax, both are imposed as excises on the transfer of property from a decedent and both take effect at the instant of the transfer." 149

In North Dakota and Orregon the state tax is called an estate tax, but it is borne proportionately by all the legatees and is not designed to take up the slack in the federal act. Oregon has also a transfer tax based on the size of the shares of the legatees, and imposed on them individually.

${ }^{230} \mathrm{~N}$. Y. Laws I909, Art. Iob.

${ }^{237}$ CAL. Codes \& Gen. Laws, (Supp. I927) tit. 501, act $8443, \S 23 / 4$.

${ }^{123}$ See VA. Code AnN. (Supp. I926) 260.

${ }^{239}$ Supra notes 107, 108, 109.

${ }^{140}$ For the estate tax see supra note 106. But cf. supra note 135 as to some state estate taxes, and supra note I03, § $3 \mathrm{I} 4$ (b) as to the burden on the beneficiaries of the policies. The state transfer taxes fall on various legatees and beneficiaries according to the size of their gifts and their relationship to the decedent. But, of course, all the taxes may be made payable out of one particular part of a decedent's estate. See 51 A. L. R. 454 (I927).

${ }^{142} 268$ U. S. 473, 498, 45 Sup. Ct. 603, 608 (1925).

112 That the transfer tax is not so inherently a different kind of tax from the estate tax may be seen from the following decisions: United States v. Perkins, 163 U. S. 625, 16 Sup. Ct. 1073 (I895), where a transfer tax on a gift to the United States was held valid; New York Trust Co. v. Eisner, 256 U. S. 345, 4I Sup. Ct. 506 (I92I), where a state transfer tax was held not deductible from the net estate, in computing the federal estate tax; Stebbins v. Riley, 268 U. S. I37, 45 Sup. Ct. 424 (I925), where a transfer tax imposed on the net estate without deducting the federal estate tax was held valid; Keith v. Johnson, 27I U. S. 1, 46 Sup. Ct. 415 (1926), where the New York transfer tax was held deductible in computing the net income of the estate during the period of administration.

And see Succession of Gheens, supra note IO7, which called the federal tax a tax on those whom the law requires to bear the burden of the tax, and so held the estate tax not deductible in computing the net estate for the levying of the state transfer tax. The states split as to this deductibility. 7 A. L. R. 714 (1920); 16 A. L. R. 674, 702 (1922). 
It is the passing of wealth at death that is the real subject of the tax. It is submitted that the same general considerations apply to the transfer taxes as to the estate tax, with reference to the taxing of insurance trusts.

\section{Application to Proceeds of Policies}

In only four states are insurance policies expressly taxable under the transfer tax: Wisconsin, ${ }^{143}$ Arkansas, ${ }^{144}$ Tennessee, ${ }^{145}$ and Montana. ${ }^{146}$ Kentucky ${ }^{14 \tau}$ expressly exempts policies payable to designated beneficiaries; North Dakota ${ }^{148}$ exempts policies in general.

The only case found adjudicating any of these taxes is $I n$ re Allis' Will, ${ }^{149}$ which held the Wisconsin tax constitutional as applied to irrevocable policies taken out prior to the passage of the tax, payable to the insured's widow, where, according to the law, the policies would revest in the insured, should the widow die first. ${ }^{150}$

The arguments against the validity of these transfer taxes are substantially the same as those against the validity of the federal tax..$^{151}$ It is noteworthy that the only difference between the state and federal taxes on policies, aside from possible administrative variations, is that rates applicable in the former are not dependent upon the size of the rest of the decedent's estate.

The great majority of the state transfer taxes are silent as to policies; and, though the general tenor of authority is to the effect

${ }^{143}$ WrS. STAT. (1927) $\S 72.0 I(7)$ : "Insurance payable upon the death of any person shall be deemed a part of his estate for the purpose of the tax, and shall be taxable to the person or persons entitled thereto."

${ }^{214}$ ARK. Dig. Stat. (Supp. I927) § I02I8 (4); only where payable to a person other than ascendant, descendant, or spouse.

${ }^{145}$ TENN. ANN. CODE (Supp. I926) § 756a-I (3); like Arkansas, supra note 92 .

${ }_{146}$ Mont. Rev. Codes (Supp. I927) § 10377.I (7) ; where over \$50,000, and "if payable to more than one person the said $\$ 50,000$ shall be prorated between such persons in proportion to the amount of insurance payable to each".

${ }^{172} \mathrm{Ky}$. Acts 1924 , c. III.

${ }^{165}$ N. D. Laws I927, c. $267, \S 2(8)$.

${ }^{140} \mathrm{I} 74$ Wis. 527,184 N. W. $38 \mathrm{I}$ (1921).

${ }^{130}$ According to the unique insurance law of Wisconsin, the insured-payer can always change the beneficiary of a policy except where it is payable to his widow, in which case it will revert to his estate if his widow should die first.

${ }^{151}$ Supra page 376 et seq. 
that policies payable to the insured's estate are taxable, ${ }^{152}$ the cases are practically unanimous in holding that policies are not gifts to take effect on death. ${ }^{153}$ The general tenor of their arguments is similar to that discussed above with reference to the constitutionality of the Federal Estate Tax. Of course, the fact that here it is a question of statutory construction as well as constitutionality makes the arguments much more persuasive.

\section{Taxation of the Securities of a Funded Trust Under the Estate Tax}

Where the trust is subject to a power of revocation in the settlor, alone or in conjunction with a third party, the securities on the settlor's death will be taxable under the express provisions of Section 302 (d). Where it is revocable only with the consent of the beneficiary, its taxability under this section is in doubt; it will probably be treated as on a par with an irrevocable trust. ${ }^{154}$ If the irrevocable trust be considered a trust for the benefit of the settlor-insured for life (a trust to apply the income to his use by paying his premiums), it would be taxable under Section 302 (c) ${ }^{155}$ If it be regarded as a trust to accumulate during the settlor's life for the benefit of the beneficiary, it would seem similarly taxable, though the few authorities on the point are unharmonious. ${ }^{15}$ As

${ }^{152}$ Matter of Knoedler, I40 N. Y. 377, 35 N. E. 601 (1893). But $c f$. North Dakota, supra note 148 .

${ }^{153}$ Irrevocable: In re Fay's Estate, 25 Misc. 468, 55 N. Y. Supp. 749 (1899) semble (only power insured had was to allow lapse); In re Bullen's Estate, I43 Wis. 512, I28 N. W. I09 (I9I0) (before present provisions), aff'd, on collateral point, 240 U. S. 625,36 Sup. Ct. 473 (I912). Though payable to executor for insured's wife and children: In re Elting, 78 Misc. 692, I40 N. Y. Supp. 238 (1912). Though policies would revert to insured if beneficiary died first: In re Parsons, II7 App. Div. 321. 102 N. Y. Supp. I68 (1907).

15 The reservation of the power to supervise investments, require trustees to execute proxies, vote stock, control execution of leases, appoint successor trustees, was held insufficient to take a trust out of the irrevocable class, in Reinecke v. Northern Trust Co., 278 U. S. 339, 49 Sup. Ct. I23 (1929).

${ }^{25 s}$ Supra note 129.

${ }^{256}$ Cf. U. S. Treas. Reg. 70, art. 18: "Where the decedent reserved only a portion of the income, only a corresponding proportion of the value of the property should be included in the gross estate, unless, however, the possession or enjoyment of the remaining portion of the transferred property, or a part thereof, was postponed until, at or after the decedent's death, in which case there should also be included in the gross estate such remaining portion or part thereof, as the case may be." But cf. McCormick v. Commissioner, 13 B. T. A. 423 (1928). 
a trust to pay the premiums for the beneficiary, it would seem to be non-taxable under Reinecke $v$. Northern Trust Company. ${ }^{157}$

Where the trust produces more income than needed to pay the premiums, the surplus may go (a) to the insured, in which case the trust res would be taxable as to the amount over and above that needed to produce an income sufficient to pay the premiums $;^{158}$ (b) to buy additional policies, in which case the entire res would remain an entity; (c) to the beneficiary, in which case the amount taxable in (a) would seem to be non-taxable under Reinecke v. Northern Trust Company. Since such trusts play an integral part in the plans of settlors for the disposition of their property after their death, it would seem that they should not escape taxation.

The problems arising in the application of state transfer taxes to the securities of a funded trust are similar to those under the estate tax. Where the trust is irrevocable, it will be taxable if it be regarded as a trust for the benefit of the settlor for life. ${ }^{158}$ If it be regarded as an accumulation, the same doubt arises. ${ }^{160}$ If it be regarded as a trust for the benefit of the beneficiary forthwith, the authorities are divided. ${ }^{161}$ Where the trust is revocable, it is, without more, taxable in some states. ${ }^{162}$ In the absence of

In Shukert v. Allen, 273 U. S. 545, 47 Sup. Ct. 46 I (I927) $S$, with a life expectancy of 16 years, conveyed to $T$ to accumulate for his three children until $195 \mathrm{I}$ - thirty years later. $S$ died a few months later. Held, not taxable as a gift to take effect on death.

${ }^{157}$ Supra note 155 .

- ${ }^{205}$ Cf. Tips v. Bass, 2 F. (2) 460 (W. D. Tex. 1927).

${ }^{209}$ Matter of Hartman, 126 Misc. 862, 215 N. Y. Supp. 802 (I926), aff'd 220 App. Div. 755, 222 N. Y. Supp. 817 (I927), in holding a funded trust on the life of a third party not an accumulation, seems to have adopted this theory. See also In re Hartman, supra note 88. See supra note IO7 as to taxability.

${ }^{200}$ Cf. People v. McCormich, 327 I11. 547, 158 N. E. 86I (1927) ; Matter of Kirby, I33 Misc. 152, 231 N. Y. Supp. 408 (1928).

I6L In re Cruger 54 App. Div. 405, 66 N. Y. Supp. 636 (I900), aff'd I66 N. Y. 602,59 N. E. II2I (IDOI); State St. Trust Co. v. Treasurer, 209 Mass. 373, 95 N. E. 85I (I9II) (taxable). Contra: State v. Welch's Estate, 235 Mich. 555, 209 N. W. 930 (1926). In Matter of Dunlap, 205 App. Div. I28, 199 N. Y. Supp. I47 (1923) the trust was held taxable where the gift over was to $X$ or his issue, the court stressing the fact that by the terms of the trust the property would revert to the settlor if $X$ died without issue during the life of the settlor. But on this point compare note $I 64$.

${ }_{10} \mathrm{~N}$. Y. TAX LAW (I928) $\S 220(2)$ expressly taxes transfers in which there may be "any change in the use or enjoyment of property included in such transfer, or the income thereof . . in the lifetime of the grantor . - by reason of any power reserved to or conferred upon the grantor - . either solely or in conjunction with any person or persons to alter, or 
statute, the authorities are divided. ${ }^{163}$ Where the settlor retains a right to the surplus income, a proportionate part of the corpus is clearly taxable. ${ }^{164}$

\section{E. Income Taxes ${ }^{165}$}

\section{Federal Income Tax}

The law here is comparatively well settled. During the continuance of the funded trust the income earned by the trust securities is taxable to the settlor, in so far as it may be used to pay premiums on insurance on his life. ${ }^{106}$ If the surplus income, if any, is, or may be, distributed to, or accumulated for, the benefit of the settlor, in his discretion "alone or in conjunction with any person not a beneficiary of the trust", ${ }^{167}$ it is taxable to him; likewise, if the surplus income is payable to a third party, but the trust is revocable. ${ }^{168}$ Where the surplus income is to be paid to a third party, it is taxable to him, whether it is paid over or not. ${ }^{169}$

to amend, or to revoke any transfer, or any portion thereof, as to the portion remaining at the time of the death of the grantor, vendor or donor, thus subject to alteration, amendment, or revocation."

Colo. Laws I927, c. II4, $\$ 2$ (5) similarly covers a power in the settlor alone, or with others, to revest himself with the property.

${ }^{163}$ In re Fosdick's Estate, I39 Atl. 318 (1927) ; Trust Co. of Norfolk v. Commonwealth, I5I Va. 883, I45 S. E. 326 (I928) (Laxable). Contra: In re Dolan's Estate, 279 Pa. 582, I24 Atl. I76 (1924); and cases cited 49 A. L. R. 857 (I927).

${ }^{104}$ See 49 A. I. R. 867 (I927) for list of cases. And see Colo. Sess. Laws 1927 , c. II4 $\$ 2(2)$ expressly covering the situation.

${ }^{10 s}$ A trust created by $A$ to pay the premiums on the life of $B$ for the benefit of $C$ raises problems, under the income tax, similar to the ordinary insurance trust created by the insured.

${ }^{186}$ Revenue ACt of 1928, § I67, 45 Stat. 840 (I928), 26 U. S. C. $\$ 2167$ (Supp. I928) : "Where any part of the income of a trust is or may be applied to the payment of premiums upon policies of insurance on the life of the grantor - . such part of the income of the trust shall be included in computing the net income of the grantor." "May be" would seem to include a case where the trustee has the discretionary right to apply the income to the policies but is not bound to do so.

${ }^{167}$ Ibid. $\$$ I67.

${ }^{316}$ Ibid $\S 166$ : "Where the grantor of a trust has, at any time during the taxable year, either alone or in conjunction with any person not a beneficiary of the trust, the power to revest in himself title to any part of the corpus of the trust, then the income of such part of the trust for such taxable year shall be included in computing the net income of the grantor." Held constitutional as applied to a trust created before the passage of the act. Corliss v. Bowers, 34 F. (2d) 656 (C. C. A. 2d, 1929).

${ }^{160}$ Reventre ACT of I928, supra note $166, \$$ I62 (b) ; cf. McCaughn v. Girard Trust Co., ig F. (2d) 2 I8 (C. C. A. 3d, I927). Note that this results in double exemptions. 
Where it is payable in the discretion of the trustee, it is taxable to the beneficiary if actually paid over. ${ }^{170}$ Where the surplus income is to be accumulated, or, in the exercise of the trustee's discretion, it is accumulated, it is taxable to the trustee, ${ }^{171}$ the estate being allowed the exemption of a single person. ${ }^{172}$ Dividends, etc., received from insurance companies during the life of the insured are not taxable as income, unless they exceed the ággregate premiums or consideration paid (whether or not during the taxable year). ${ }^{173}$ After the death of the insured, the proceeds paid over are not taxable income, but, if they are held by the insurer under an agreement to pay interest, the interest is taxable income. ${ }^{174}$ Of course, if the trust continues, the income of the augmented trust will be taxed in the usual fashion.

Since the Federal Income Tax is graduated, a considerable saving is sometimes possible through the creation of an insurance trust. For example, on net incomes over $\$ 100,000$ there is a twenty per cent surtax on the excess over $\$ 100,000$, in addition to a five per cent normal tax on the excess over $\$ 8,000$. On the other hand, there is no surtax on incomes of $\$ x 0,000$ or under. Hence if a settlor creates a trust in which the income is taxable to a trust or beneficiary whose net income will still be less than $\$ 10,000$, he saves the twenty per cent surtax on that sum. If the income of the trust or beneficiary is over $\$ 10,000$, there is still a considerable saving, since the surtax varies with the amount of the income. If the income of the trust or beneficiary is less than $\$ 8,000$, there is a similar saving on the normal tax.

\section{State Income Taxes ${ }^{175}$}

There are no express provisions as to who bears the burden on the income used to pay the premiums. In New York the surrogate has held them taxable to the insured, in a trust on the

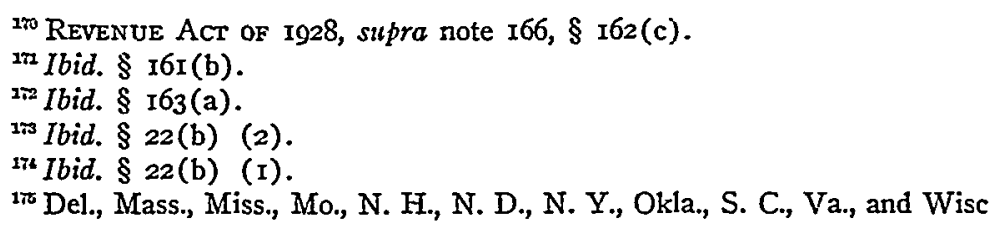


life of the settlor's son. ${ }^{178}$ This is a peculiar decision. Consider the case of a rich uncle creating a large trust on the life of his poor nephew, for the benefit of the nephew's children; would the nephew have to bear the burden? Could he, unless there was sufficient surplus income to cover the tax? Suppose the trust contained a provision for the use of all surplus income for the purchase of additional policies? It would seem that the insured is a mere figurehead. In New Hampshire the tax would fall on the ultimate beneficiary, if ascertained and an inhabitant of the state. ${ }^{177}$ In the rest of the states it would seem that the income would be taxable to the trustee, probably by way of analogy to an accumulation. This seems to be the most equitable method, and, incidentally, it would probably bring more revenue to the state, since there would be no exemptions for dependents. Where the surplus income is actually paid or is payable, though this is not done, it is taxable to the beneficiary. However, in New York, where the trustee has a discretion as to the distribution, it is taxable to him, although he actually pays it over to some beneficiary. ${ }^{178}$ A majority of the states grant full exemption to policy returns during the life of the insured. ${ }^{179}$ After the death of the insured the federal provisions generally apply.

\section{CONCLUSION}

A subject like insurance trusts reflects the peculiar difficulty of writing anything adequate about a contemporary business topic, if one restricts his discussion largely to legal material. The lawyer dealing with insurance trusts is first faced with the problem of drafting instruments. He needs, of course, to consider possible legal complications, but he must also take into account the business situation of the parties. If this article were really complete it would attempt to apply its suggestions to some of the concrete tasks of the legal draftsman.

${ }^{178}$ In re Hartman, supra note 88. § I0.

${ }^{17 \pi}$ N. H. Laws I926, c. 65, § 9. See also Mass. Gen. Laws (I921) c. 62,

${ }^{178}$ People v. Gilchrist, 244 N. Y. 56, I54 N. E. 821 (I926).

${ }^{139}$ Del. Laws 1929, c. $8, \S 3 a(2)$. South Carolina has a limited exemption like the federal tax. 
A second criticism which might be advanced may be less valid. It may be urged that it is impossible to write a useful legal article about an institution that has never been before the courts for interpretation of its powers and privileges. The chances of error or irrelevance are certainly present. Nevertheless the challenge seems worth accepting. If the combined acuteness of those interested in insurance trust problems is sufficient, the law of the subject may continue to be made almost indefinitely outside the scope of actual legal decision.

\section{APPENDIX}

Those states having no accumulations statute are governed by the local rule against perpetuities.

\begin{tabular}{|c|c|c|}
\hline State & Perpetuities & Accumulations \\
\hline Alabama & $\begin{array}{l}\text { Lands may be conveyed to } \\
\text { the wife or children, and } \\
\text { heirs of the body of the } \\
\text { survivors, if they come of } \\
\text { age, and, in default thereof, } \\
\text { over; but conveyances to } \\
\text { others are limited to three } \\
\text { lives in being at the date of } \\
\text { the conveyance, plus Io years. } \\
\text { ALA. Crv. C oDE (I928) } \\
\text { §6922. }\end{array}$ & $\begin{array}{l}\text { Trusts or estates "for the } \\
\text { p u } \mathrm{r} \text { pose of accumulation } \\
\text { only" are void } a b \text { initio if } \\
\text { they exceed ten years; ex- } \\
\text { cept the case of a minority. } \\
\text { Ibid. } \$ 6914 \text {. } \\
\text { No provision as to the dis- } \\
\text { position of the released in- } \\
\text { come. }\end{array}$ \\
\hline Alaska & Common law & None \\
\hline Arizona & $\begin{array}{l}\text { Two lives in being, plus } \\
\text { twenty-one years. ARIz. CIv. } \\
\text { CoDE (I9I3) } \$ \$ 4680,468 \mathrm{I} \text {; } \\
\text { Ariz. Laws Ig2I, c. I4I. }\end{array}$ & $\begin{array}{l}\text { Realty: Valid during a mi- } \\
\text { nority. ARIz. Crv. CODE } \\
\text { (I9I3) } \$ 4702 \text {. } \\
\text { Personalty: None. } \\
\text { No provision as to the dis- } \\
\text { position of the released in- } \\
\text { come. }\end{array}$ \\
\hline Arkansas & Common law & None \\
\hline California & $\begin{array}{l}\text { Lives in being, plus a minor- } \\
\text { ity or an absolute period of } \\
\text { twenty-five years. CAL. CIv. } \\
\text { CoDE (Deering, I923) \$\$ 715, } \\
771,772 \text {. }\end{array}$ & $\begin{array}{l}\text { Valid for a minority. The } \\
\text { released income goes to the } \\
\text { presumptive holder of the } \\
\text { next eventual estate. Ibid. } \\
\S 733 \text {. }\end{array}$ \\
\hline
\end{tabular}




\begin{tabular}{|c|c|c|}
\hline State & Perpetuities & Accumulations \\
\hline Colorado & Common law & None \\
\hline Connecticut & Common law & None \\
\hline Delaware & Common law & None \\
\hline $\begin{array}{l}\text { District of } \\
\text { Columbia }\end{array}$ & $\begin{array}{l}\text { Lives in being, plus twenty- } \\
\text { one years. D. C. CODE (I925) } \\
\S \text { I023. }\end{array}$ & None \\
\hline Florida & Common law & None \\
\hline Georgia & $\begin{array}{l}\text { Lives in being, plus twenty- } \\
\text { one years, plus gestation. } \\
\text { GA. ANN. CoDE (Michie, } \\
\text { I926) } \$ 3678 \text {. }\end{array}$ & None \\
\hline Hawaii & Common law & None \\
\hline Idaho & $\begin{array}{l}\text { Lives in being, plus a minor- } \\
\text { ity. IDABO Co M P. STAT. } \\
\text { (I9I9) \&\$ 5335, 5340. }\end{array}$ & None \\
\hline
\end{tabular}

\begin{tabular}{ll}
\hline Illinois Common law & The Thellusson Act, even in- \\
cluding the saving clauses \\
for debts and portions (c. 3, \\
par. I45). Provision as to \\
the disposition of the re- \\
leased income similar to \\
Thellusson Act. See ILI. \\
STAT. ANN. (I9I3) \& I89.
\end{tabular}

Indiana . Realty: Lives in being, plus
a minority.

Personalty: Lives in being.

IND. AnN. Stat. (Burns, I926) $\S$ I217I. Section I 3416 requires the measuring lives

Realty: None. Ibid. § I217.

Personalty: Valid during a minority.

No provision as to disposito be specified.

Iowa Lives in being, plus twenty- None one years. IowA CODE (I927)

§ 10127.

\begin{tabular}{lll}
\hline Kansas & Common law & None \\
\hline
\end{tabular}

Kentucky

Lives in being, plus twenty- None one years, plus ten months.

Ky. Stat. (Carroll, I9I5)

$\S 2360$. 


\begin{tabular}{|c|c|c|}
\hline State & Perpetuities & Accumulations \\
\hline Louisiana & $\begin{array}{l}\text { Unknown as such; section I6 } \\
\text { of the constitution forbids } \\
\text { the creation of trust estates, } \\
\text { except that the legislature } \\
\text { may authorize them, pro- } \\
\text { vided (a) they terminate } \\
\text { within ten years, (b) they } \\
\text { terminate within ten years of } \\
\text { the majority of a natural } \\
\text { person. }\end{array}$ & Unknown \\
\hline Maine & Common law & None \\
\hline Maryland & Common law & None \\
\hline Massachusetts & $\begin{array}{l}\text { Common law, plus limitation } \\
\text { of trusts of realty to thirty } \\
\text { years. MASS. GEN. LAws } \\
\text { (I92I) § I8435. }\end{array}$ & None \\
\hline Michigan & $\begin{array}{l}\text { Realty: Two lives, plus mi- } \\
\text { nority. MICH. CoMp. LAws } \\
\text { (Cahi11, I9I5) \&\& Ir } 533 \text {, } \\
\text { II534. } \\
\text { Personalty: Common law. }\end{array}$ & $\begin{array}{l}\text { Realty: Valid during a mi- } \\
\text { nority. Ibid. \& II } 555 \text {. } \\
\text { Personalty: None. } \\
\text { The released income goes to } \\
\text { the presumptive holder of the } \\
\text { next eventual estate. }\end{array}$ \\
\hline Minnesota & $\begin{array}{l}\text { Two lives, plus twenty-one } \\
\text { years. MrNN. STaT. (Mason, } \\
\text { I927) §§ 8044, 8045, 8046. }\end{array}$ & $\begin{array}{l}\text { Realty: Valid during a mi- } \\
\text { nority. Ibid. \$ } 8067 . \\
\text { Personalty: None. } \\
\text { The released income goes to } \\
\text { the presumptive holder of } \\
\text { the next eventual estate. } \\
\text { Ibid. } \$ 8070 \text {. }\end{array}$ \\
\hline Mississippi & $\begin{array}{l}\text { Common law. But see Mrss. } \\
\text { ANN. CoDE (Hemingway, } \\
\text { Ig27) \& } 2424 .\end{array}$ & None \\
\hline Missouri & Common law & None \\
\hline Montana & $\begin{array}{l}\text { Realty: Iives in being, plus } \\
\text { a m i n o rity. MoNT. REv. } \\
\text { CoDes (Ch o a te, I921) } \\
\$ \S 6705,6706 . \\
\text { Personalty: Lives in being. } \\
\text { Ibid. } \$ \$ 6734,6736 .\end{array}$ & $\begin{array}{l}\text { Realty: None. } \\
\text { Personalty: Valid during a } \\
\text { minority. Ibid. } \$ \$ 670-6713 . \\
\text { The released income goes to } \\
\text { the presumptive holder of } \\
\text { the next eventual interest } \\
\text { Ibid. } \$ 67 \text { I5. }\end{array}$ \\
\hline Nebraska & Common law & None \\
\hline Nevada & Common law & None \\
\hline
\end{tabular}




\begin{tabular}{|c|c|c|}
\hline State & Perpetuities & Accumulations \\
\hline New Hampshire & Common law & None \\
\hline New Jersey & Common law & None \\
\hline New Mexico & $\begin{array}{l}\text { Common law. But see N. M. } \\
\text { ANN. Stat. (I9r5) } § 4763 \text {. }\end{array}$ & None \\
\hline New York & $\begin{array}{l}\text { Realty: Two lives in being, } \\
\text { plus a minority. } \\
\text { Personalty: Two lives in be- } \\
\text { ing. N. Y. ANN. CoNs. } \\
\text { LAws (2d ed. I91\%) } 7293 \\
\text { et seq., } 73 \mathrm{r} 3 \text { et seq. }\end{array}$ & $\begin{array}{l}\text { Realty: Valid during a mi- } \\
\text { nority. } \\
\text { Personalty: Valid during a } \\
\text { minority. } \\
\text { The released income goes to } \\
\text { the presumptive holder of } \\
\text { the next eventual estate. }\end{array}$ \\
\hline North Carolina & Common law & None \\
\hline North Dakota & $\begin{array}{l}\text { Realty: Lives in being, plus } \\
\text { a minority. N. D. CoMr. } \\
\text { LAws ANN. (1913) \$5287. } \\
\text { Personalty: Lives in being. } \\
\text { Ibid. \$ 5315. }\end{array}$ & $\begin{array}{l}\text { Realty: Valid during a mi- } \\
\text { nority. Ibid. } \$ 5291 . \\
\text { Personalty: Valid during a } \\
\text { minority. Ibid. }\end{array}$ \\
\hline Ohio & $\begin{array}{l}\text { Realty: Lives in being. OHro } \\
\text { GEN. CODE (P g e, I926) } \\
\text { \$ } 8622 . \\
\text { Personalty: In doubt-prob- } \\
\text { ably common law. }\end{array}$ & None \\
\hline Oklahoma & $\begin{array}{l}\text { Realty: Lives in being, plus } \\
\text { a minority. O K L A. CoMr. } \\
\text { STAT. ANN. (I92I) \$ } 8410 . \\
\text { Personalty: Lives in being. } \\
\text { Ibid. \$ 8413. }\end{array}$ & None \\
\hline Oregon & Common law & None \\
\hline Pennsylvania & Common law & $\begin{array}{l}\text { Reènactment of the Thellus- } \\
\text { son Act. } \\
\text { Provision for the disposition } \\
\text { of the released income simi- } \\
\text { lar to Thelluson Act. }\end{array}$ \\
\hline Porto Rico & Probably common law & None \\
\hline Rhode Island & Common law & None \\
\hline South Carolina & Common law & None \\
\hline
\end{tabular}




\begin{tabular}{|c|c|c|}
\hline State & Perpetuities & Accumnlations \\
\hline South Dakota & $\begin{array}{l}\text { Lives in being, plus a minor- } \\
\text { ity. S. D. REv. CoDE (I9I9) } \\
\S \S 294,322 \text {. }\end{array}$ & $\begin{array}{l}\text { Valid during a minority. } \\
\text { Ibid. \&299. } \\
\text { The released income goes to } \\
\text { the presumptive holder of } \\
\text { the next eventual estate. } \\
\text { Ibid. } \S 303 \text {. }\end{array}$ \\
\hline Tennessee & Common law & None \\
\hline Texas & Common law & None \\
\hline Utah & Common law & None \\
\hline Vermont & Common law & None \\
\hline Virginia & Common law & None \\
\hline Washington & Common law & None \\
\hline West Virginia & Common law & None \\
\hline Wisconsin & $\begin{array}{l}\text { Lives in being, plus thirty } \\
\text { years. WIS. STAT. (1927) } \\
\S 230.15 .\end{array}$ & $\begin{array}{l}\text { Realty: Valid for a minority. } \\
\text { Personalty: N on e. Ibid. } \\
\text { \$230.37. } \\
\text { The released income goes to } \\
\text { the presumptive holder of } \\
\text { the next eventual estate. } \\
\text { Ibid. } \$ 230.14 \text {. }\end{array}$ \\
\hline
\end{tabular}

